\title{
The relative contributions of biological and abiotic processes to carbon dynamics in subarctic sea ice
}

\author{
Dorte Haubjerg Søgaard • David N. Thomas • Søren Rysgaard • \\ Ronnie Nøhr Glud • Louiza Norman • Hermanni Kaartokallio • \\ Thomas Juul-Pedersen • Nicolas-Xavier Geilfus
}

Received: 6 December 2012/Revised: 9 July 2013/Accepted: 10 August 2013/Published online: 4 September 2013

(C) The Author(s) 2013. This article is published with open access at Springerlink.com

\begin{abstract}
Knowledge on the relative effects of biological activity and precipitation/dissolution of calcium carbonate $\left(\mathrm{CaCO}_{3}\right)$ in influencing the air-ice $\mathrm{CO}_{2}$ exchange in sea-icecovered season is currently lacking. Furthermore, the spatial and temporal occurrence of $\mathrm{CaCO}_{3}$ and other biogeochemical parameters in sea ice are still not well described. Here we investigated autotrophic and heterotrophic activity as well as the precipitation/dissolution of $\mathrm{CaCO}_{3}$ in subarctic sea ice in South West Greenland. Integrated over the entire ice season (71 days), the sea ice was net autotrophic with a net carbon fixation of $56 \mathrm{mg} \mathrm{C} \mathrm{m}^{-2}$, derived from a sea-icerelated gross primary production of $153 \mathrm{mg} \mathrm{C} \mathrm{m}^{-2}$ and a bacterial carbon demand of $97 \mathrm{mg} \mathrm{C} \mathrm{m}^{-2}$. Primary production contributed only marginally to the $\mathrm{TCO}_{2}$ depletion of the sea ice (7-25\%), which was mainly controlled by physical export by brine drainage and $\mathrm{CaCO}_{3}$ precipitation. The net biological production could only explain $4 \%$ of this sea-ice-driven $\mathrm{CO}_{2}$ uptake. Abiotic processes contributed to an air-sea $\mathrm{CO}_{2}$ uptake of $1.5 \mathrm{mmol} \mathrm{m}^{-2}$ sea ice day ${ }^{-1}$, and
\end{abstract}

D. H. Søgaard ( $\square)$ · S. Rysgaard · R. N. Glud ·

T. Juul-Pedersen

Greenland Climate Research Centre (C/O Greenland

Institute of Natural Resources), Kivioq 2, Box 570,

3900 Nuuk, Greenland

e-mail: doso@natur.gl

D. H. Søgaard · R. N. Glud

University of Southern Denmark, Campusvej 55,

5230 Odense M, Denmark

D. N. Thomas - L. Norman

School of Ocean Sciences, Bangor University,

Menai Bridge, Anglesey LL59 5AB, UK

D. N. Thomas · H. Kaartokallio

Finnish Environment Institute, Marine Research Centre,

Erik Palmenin Aukio 1, 00560 Helsinki, Finland dissolution of $\mathrm{CaCO}_{3}$ increased the air-sea $\mathrm{CO}_{2}$ uptake by $36 \%$ compared to a theoretical estimate of melting $\mathrm{CaCO}_{3}-$ free sea ice. There was a considerable spatial and temporal variability of $\mathrm{CaCO}_{3}$ and the other biogeochemical parameters measured (dissolved organic and inorganic nutrients).

Keywords Subarctic $\cdot$ Sea ice $\cdot$ Spatial variability . $\mathrm{CaCO}_{3} \cdot$ Net biological production $\cdot$ DOC and DON

\section{Introduction}

Sea ice has previously been considered to be an impermeable barrier to gas exchange, and global climate models do not included $\mathrm{CO}_{2}$ exchange with the oceans during periods of closed ice cover (Tison et al. 2002; Loose et al. 2011; Rysgaard et al. 2011). However, recent observations of gas exchange using both tower-based micrometeorological approaches and chamber sampling indicate that

D. N. Thomas · S. Rysgaard

Arctic Research Centre, Aarhus University, C.F. Møllers Allé 8, bldg. 1110, 8000 Aarhus C, Denmark

S. Rysgaard · N.-X. Geilfus

Centre for Earth Observation Science, CHR Faculty

of Environment Earth and Resources, University of Manitoba, 499 Wallace Building, Winnipeg, MB R3T 2N2, Canada

R. N. Glud

Scottish Association for Marine Science, Scottish Marine

Institute, Oban, UK 
uptake and degassing of $\mathrm{CO}_{2}$ does occur over sea ice (Semiletov et al. 2004; Zemmelink et al. 2006; Delille et al. 2007; Nomura et al. 2010; Miller et al. 2011; Papakyriakou and Miller 2011; Geilfus et al. 2012). In addition, the recognition that there are extensive and active microorganism communities within sea ice, and the finding of the sea-ice-driven carbon pump (Rysgaard et al. 2007), has changed this general perception. Sea ice is now considered to be an active component in the biogeochemical cycling of carbon in ice-covered waters.

During winter, as sea ice grows, salts are partly rejected from the sea ice and partly trapped within the sea ice structure, concentrated into brine pockets, tubes, and channels (Weeks and Ackley 1986; Petrich and Eicken 2010). As the temperature decreases, brine salinity and concentration of solutes and gases increase in brine, and the resulting brine $p \mathrm{CO}_{2}$ is furthermore, strongly influenced by brine drainage and $\mathrm{CaCO}_{3}$ precipitation (Papadimitriou et al. 2007, 2012; Rysgaard et al. 2011, 2012).

Brine drainage from sea ice causes the formation of highly saline dense cold water that sinks to deeper layers and contributes to the global ocean circulation. Furthermore, brine drainage may also change the $p \mathrm{CO}_{2}$ concentrations below sea ice by releasing dissolved gasses and solutes into the water column (Gibson and Trull 1999; Semiletov et al. 2004, 2007; Delille 2006). $\mathrm{CaCO}_{3}$ precipitation can occur in sea ice due to the changes in the mineral-liquid thermodynamic equilibrium (Marion 2001). Ikaite, a hexahydrate polymorph of calcium carbonate $\left(\mathrm{CaCO}_{3} \cdot 6 \mathrm{H}_{2} \mathrm{O}\right)$, begins to precipitate at $-2.2{ }^{\circ} \mathrm{C}$ and has been found in both Antarctic and Arctic sea ice (Dieckmann et al. 2008, 2010; Rysgaard et al. 2012, 2013; Fischer et al. 2013; Geilfus et al. 2013). $\mathrm{CO}_{2}$ is expelled more efficiently from the ice than total alkalinity (TA), because alkalinity is trapped in ikaite crystals within the interstices between the ice crystals and sea ice becomes enriched in TA (Rysgaard et al. 2013). Studies in the Arctic suggest that, due to brine drainage, $\mathrm{CO}_{2}$ and $\mathrm{TCO}_{2}$ can be transported below the pycnocline and, subsequently, incorporated into intermediate and deep-water masses (Rysgaard et al. 2007, 2011). A combination of the transport of $\mathrm{CO}_{2}$, $\mathrm{TCO}_{2}$, and meltwater from sea ice will lead to a decrease in surface $p \mathrm{CO}_{2}$ with a corresponding increase in the air-sea $\mathrm{CO}_{2}$ flux.

During spring, when the sea ice melts, dissolution of $\mathrm{CaCO}_{3}$ (Nedashkovsky et al. 2009), autotrophic assimilation of $\mathrm{CO}_{2}$ (Søgaard et al. 2010), and dilution of brine by melting sea ice are all processes that can decrease the $p \mathrm{CO}_{2}$ of the brines and, ultimately, of the surface waters (Geilfus et al. 2012). This will result in a lowering of the surface seawater $\mathrm{CO}_{2}$, thereby causing an increase in the air-sea flux of $\mathrm{CO}_{2}$ (Rysgaard et al. 2011, 2012). However, the significance of $\mathrm{CaCO}_{3}$ precipitation/dissolution in sea ice on the air-sea flux of $\mathrm{CO}_{2}$ depends on the sea ice permeability, the timing and location of $\mathrm{CaCO}_{3}$ precipitation, the rate of $\mathrm{CaCO}_{3}$ precipitation, and the fate of the $\mathrm{CaCO}_{3}$ (Delille 2006).

Another potential process in sea ice that could counteract an atmospheric $\mathrm{CO}_{2}$ draw-down is heterotrophic respiration releasing $\mathrm{CO}_{2}$ (Deming 2010; Søgaard et al. 2010).

The understanding of sea ice $\mathrm{CO}_{2}$ dynamics and whether or not the polar regions are, or will be, a source or a sink for $\mathrm{CO}_{2}$ exchange is of fundamental importance for understanding global air-ocean $\mathrm{CO}_{2}$ dynamics. Several studies have focused on the spatial heterogeneity of sea ice algae and/or bacteria, as well as key biogeochemical parameters (Gosselin et al. 1986; Eicken et al. 1991; Rysgaard et al. 2001; Granskog et al. 2005; Steffens et al. 2006; Mikkelsen et al. 2008; Søgaard et al. 2010; Fischer et al. 2013). However, to date, few attempts have been made to investigate the spatial and temporal variability of $\mathrm{CaCO}_{3}$ and the relationship between $\mathrm{CaCO}_{3}$ precipitation and other biogeochemical parameters.

Factors affecting the precipitation, growth, and dissolution of $\mathrm{CaCO}_{3}$ crystals in natural sea ice are still poorly understood (Rysgaard et al. 2012). However, it has been shown that orthophosphate can inhibit the crystallization of the anhydrous forms of $\mathrm{CaCO}_{3}$ (Bischoff et al. 1993; Lin and Singer 2006) but does not interact with ikaite (Bischoff et al. 1993; Buchardt et al. 2001). Furthermore, high concentrations of dissolved organic matter (DOM) can inhibit $\mathrm{CaCO}_{3}$ precipitation in natural environments (Berner et al. 1978; Zullig and Morse 1988). Since sea ice is known to have high concentrations of both DOM and phosphate, especially associated with high biological activity (Thomas et al. 2010), it is pertinent to study these together with $\mathrm{CaCO}_{3}$ dynamics in ice.

The objectives of this study were (1) to investigate the factors that control the spatial and temporal distribution of $\mathrm{CaCO}_{3}$, dissolved organic carbon and nitrogen (DOC, $\mathrm{DON}), \mathrm{TCO}_{2}$, TA, inorganic nutrients, bulk salinity, and temperature as well as primary and bacterial productivity in subarctic first-year sea ice, (2) to discuss the potentially synergy between these parameters, and (3) to understand how they can affect the sea ice $\mathrm{CO}_{2}$ system.

\section{Materials and methods}

Sampling was conducted from February 17 to May 1, 2010, on first-year fast ice in Kapisigdlit Bight (60 km to the SW of Nuuk), SW Greenland $\left(64^{\circ} 26^{\prime} \mathrm{N} 50^{\circ} 13^{\prime} \mathrm{W}\right.$; Fig. 1). During this period, sea ice thickness gradually reduced from the maximum thickness of $81 \mathrm{~cm}$ until it completely melted. A maximum snow thickness of $7 \mathrm{~cm}$ was measured 


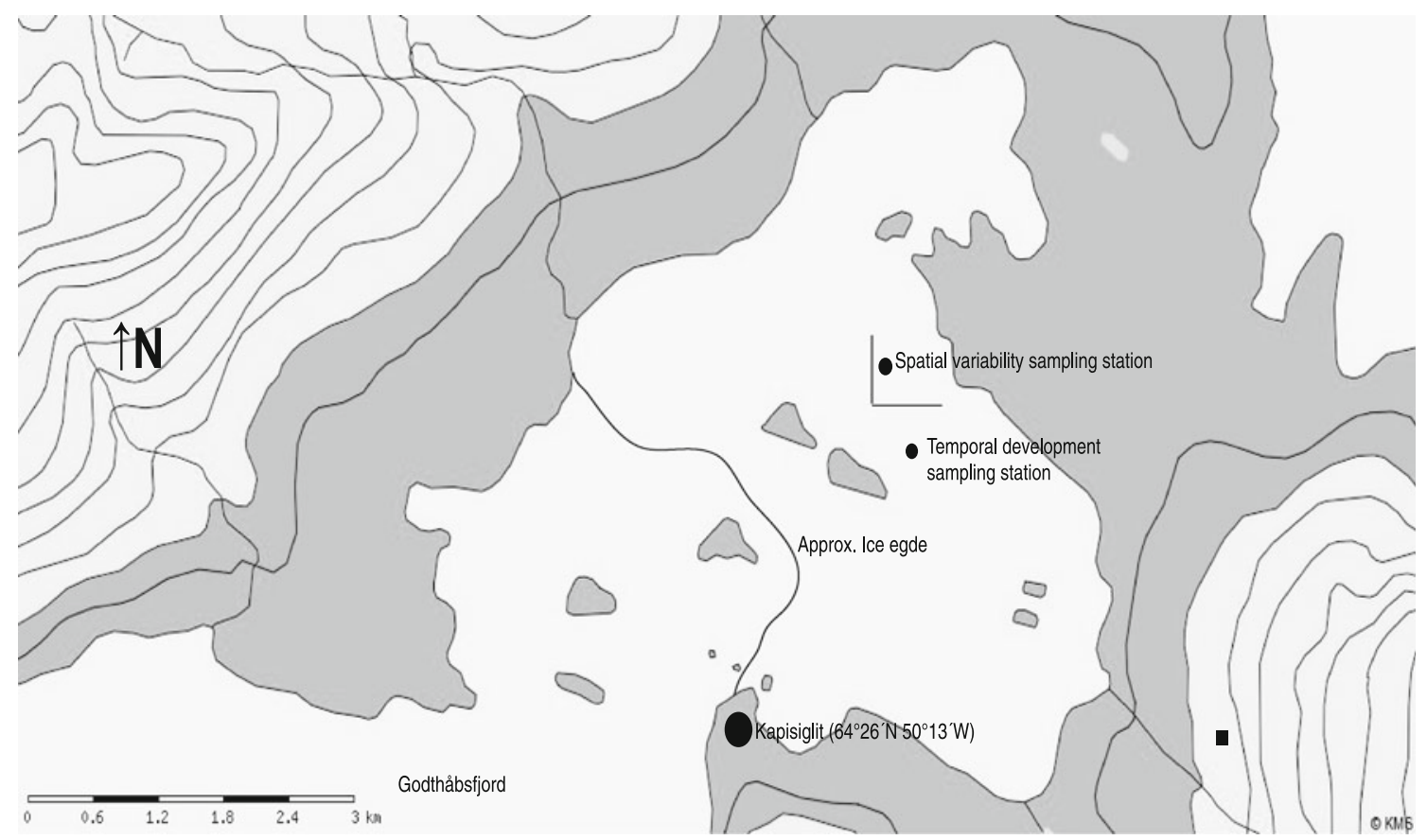

Fig. 1 Map showing the sea ice area in Kapisigdlit in SW Greenland and the temporal development and spatial variability sampling stations

in March. The water column in the Kapisigdlit Bight was fully mixed and the salinity under the sea ice varied between 33 and 33.5. The water depth under the sea ice was 30-40 meter. More details on the oceanographic conditions in the Godthåbsfjord are provided by Mortensen et al. (2011).

Two sampling designs were used:

1. Spatial variability was investigated over a perpendicular $x-y$ transect covering $0.07 \mathrm{~km}^{2}$ that was investigated on March 11 and April 8, 2010 (See Fig. 1 for location of these). The parameters sampled in this part of the work were $\mathrm{CaCO}_{3}$, dissolved organic carbon and nitrogen (DOC, DON), inorganic nutrients $\left(\mathrm{PO}_{4}{ }^{3-}\right.$, $\mathrm{Si}(\mathrm{OH})_{4}, \mathrm{NO}_{2}^{-}, \mathrm{NO}_{3}^{-}$, and $\left.\mathrm{NH}_{4}^{+}\right)$, temperature, salinity, and snow and sea ice thickness.

2. The temporal development of $\mathrm{CaCO}_{3}, \mathrm{TCO}_{2}, \mathrm{TA}$, inorganic nutrients, DOC, DON, primary production, bacteria production, bulk salinity, snow and sea ice thickness, and temperature was also investigated at a single location in the study area (Fig. 1) every 2-3 weeks from February to May 2010 (i.e. 17 February, 10, 11, 12 and 15 March, 8 April and 1 May).

\section{Spatial variability}

In both of the transect surveys (i.e., March 11 and April 8, 2010), 25 sea ice cores were taken along a 266-m-long perpendicular $x-y$ transect. The cores were collected at distances of $0,0.2,0.4,0.6,0.8,1,3,9,20,42,64,128$, and $266 \mathrm{~m}$ in both $\mathrm{x}$ and $\mathrm{y}$ directions. At each sampling point, a sea ice core was collected using a MARK II coring system (Kovacs Enterprises Ltd) and an overlying snow sample was collected using a small shovel. The air temperature was measured $2 \mathrm{~m}$ above the snow, and vertical profiles of temperatures within the ice were measured using a calibrated thermometer $\left(\right.$ Testo $\left.^{\circledR}\right)$. Sea ice temperature measurements were complemented by a custom-built string of thermistors that were frozen into the sea ice from 11 March until 8 April. The thermistor string data were recorded every $6 \mathrm{~h}$ at a spatial resolution of $4 \mathrm{~cm}$.

The retrieved ice cores were cut into $12 \mathrm{~cm}$ sections with a stainless steel saw and placed in plastic containers and transported back to the laboratory in dark thermoinsulated boxes. Sea ice and snow samples were slowly melted in the dark at $3 \pm 1{ }^{\circ} \mathrm{C}$, which took between 2 and 3 days. We measured all the parameters in all sea ice sections. However, we only report data from the top and bottom section as they are the most important.

To determine the amount of $\mathrm{CaCO}_{3}$ within the ice and snow, between 300 and $500 \mathrm{ml}$ of melted ice or snow was divided into three subsamples and filtered $\left(3 \pm 1^{\circ} \mathrm{C}\right)$ through pre-combusted $\left(450{ }^{\circ} \mathrm{C}, 6 \mathrm{~h}\right)$ Whatman ${ }^{\circledR} \mathrm{GF} / \mathrm{F}$ filters. The exact volume of the filtered meltwater was measured. The filters were transferred to tubes $(12 \mathrm{ml}$ Exetainer $\left.{ }^{\circledR}\right)$ containing $20 \mu \mathrm{HgCl}_{2}(5 \% \mathrm{w} / \mathrm{v}$, saturated solution) to avoid microbial activity during storage and $12 \mathrm{ml}$ deionized water with a known $\mathrm{TCO}_{2}$ concentration. The tubes were then spiked with $300 \mu \mathrm{l}$ of $8.5 \%$ 
phosphoric acid to convert $\mathrm{CaCO}_{3}$ on the filters to $\mathrm{CO}_{2}$, and after coulometric analysis (Johnson et al. 1993) of $\mathrm{CO}_{2}$ the $\mathrm{CaCO}_{3}$ concentration was calculated.

At each sampling occasion, samples from different ice depth horizons were inspected under the microscope to check for the presence of microorganisms with calcium carbonate external structures such as coccolithophores and foraminifers. These inspections showed that no microorganisms with calcium carbonate external structures were present in any of the samples.

The remaining meltwater was filtered through $25-\mathrm{mm}$ Whatman ${ }^{\circledR}$ GD/X disposable syringe filters (pore size $0.45 \mu \mathrm{m}$ ). A subsample of the filtrate was transferred to precombusted glass vials; $100 \mu \mathrm{l}$ of $85 \%$ phosphoric acid was added; and the vials were frozen for later analyses of DOC. The remaining filtrate was transferred to pre-combusted $\left(450{ }^{\circ} \mathrm{C}, 6 \mathrm{~h}\right)$ and alkali-washed glass vials and frozen for later analysis of $\mathrm{DON}, \mathrm{PO}_{4}{ }^{3-}, \mathrm{NO}_{3}{ }^{-}, \mathrm{NO}_{2}{ }^{-}, \mathrm{Si}(\mathrm{OH})_{4}$, and $\mathrm{NH}_{4}{ }^{+}$. The DOC, DON, and nutrient samples were frozen at $-19{ }^{\circ} \mathrm{C}$ until analysis. DOC was measured by high-temperature catalytic oxidation, using a MQ 1001 TOC Analyzer (Qian and Mopper 1996). The concentrations of $\mathrm{NO}_{3}, \mathrm{NO}_{2}{ }^{-}$, $\mathrm{PO}_{4}{ }^{3-}$, and $\mathrm{Si}(\mathrm{OH})_{4}$ were determined by standard colorimetric methods (Grasshoff et al. 1983) as adapted for flow injection analysis (FIA) on a LACHAT Instruments QuickChem 8000 autoanalyzer (Hales et al. 2004). The $\mathrm{PO}_{4}{ }^{3-}$ samples from the first sampling was contaminated, and therefore we did not include them. The concentration of $\mathrm{NH}_{4}{ }^{+}$was determined with the fluorometric method of Holmes et al. (1999) using a HITACHI F2000 fluorescence spectrophotometer. The concentration of DON was determined by subtraction of the concentration of DIN $\left(\mathrm{DIN}=\left[\mathrm{NO}_{3}{ }^{-}\right]+\left[\mathrm{NO}_{2}{ }^{-}\right]+\left[\mathrm{NH}_{4}{ }^{+}\right]\right)$from that of the total dissolved nitrogen determined by FIA on the LACHAT autoanalyzer, using online peroxodisulphate oxidation coupled with UV radiation at pH 9.0 and $100{ }^{\circ} \mathrm{C}$ (Kroon 1993).

The conductivity of the melted sea ice sections was measured (Thermo Orion 3-star with an Orion 013610MD conductivity cell), and values were converted to bulk salinity (Grasshoff et al. 1983). The brine volumes of the original sea ice samples were calculated from the measured bulk salinity and temperature and a fixed density of $0.917 \mathrm{~g} \mathrm{~cm}^{-3}$ according to Leppäranta and Manninen (1988) for temperatures $>-2{ }^{\circ} \mathrm{C}$ and according to Cox and Weeks (1983) for temperatures $<-2{ }^{\circ} \mathrm{C}$.

Spatial autocorrelation (Legendre and Legendre 1998) was used to analyze the correlation of the horizontal and vertical distribution of $\mathrm{CaCO}_{3}$ concentration, $\mathrm{DOC}, \mathrm{DON}$, inorganic nutrients, temperature, and salinity as well as the snow and sea ice thickness. Autocorrelation was estimated by Moran's I coefficients (Moran 1950; Legendre and Legendre 1998). This coefficient was calculated for each of the following intervals along the transect (classes of distance): $0-0.25,0.25-0.50,0.50-1.5,1.5-2.5,2.5-5.0$, $5.0-10,10-50,100-150,150-200,200-250$, and $>250 \mathrm{~m}$. The autocorrelation coefficients estimated by the Moran's I coefficient were tested for significance according to the method described in Legendre and Legendre (1998). A 2-tailed test of significance was used. Positive $(+)$ indicates positive autocorrelation (correlation) and negative (-) indicates negative autocorrelation. A zero (0) value indicates a random spatial pattern. We applied a significance level of $P<0.05$. Pearson's correlation was used to find the correlation between the parameters. Furthermore, a full factorial generalized linear model (GLM) including time, depth, and position as explanatory variables, which was reduced based on Akaike's Information Criterion (AIC), was applied. The same model was applied for several dependent variables: position (horizontal), depth (vertical), and time on $\mathrm{CaCO}_{3}$ concentration, bulk salinity, DOC, and DON.

\section{Temporal development}

On each of the 7 sampling occasions for the temporal study, triplicate ice cores and environmental parameters were collected from a defined area $\left(5 \mathrm{~m}^{2}\right)$, and samples were processed as described above.

Primary production was measured (Søgaard et al. 2010) on 4 occasions (i.e. 17 February, 11 March, 8 April, and 1 May). In short, primary production was determined on melted sea ice samples (melted within $48 \mathrm{~h}$ in the dark at $3 \pm 1^{\circ} \mathrm{C}$ ). The potential primary production in the sea ice at different sea ice depths (i.e. $12 \mathrm{~cm}$ sections) was measured in the laboratory cold room at 3 irradiances (72, $50,14 \mu \mathrm{mol}$ photons $\mathrm{m}^{-2} \mathrm{~s}^{-1}$ ) and corrected with one dark incubation, using the $\mathrm{H}^{14} \mathrm{CO}_{3}^{-}$incubation technique (incubation time was $5 \mathrm{~h}$ ). The potential primary production measured in the laboratory at different sea ice depths was plotted against the three laboratory light intensities 42 , 21 , and $9 \mu \mathrm{mol}$ photon $\mathrm{m}^{-2} \mathrm{~s}^{-1}$ and fitted to the following function described by Platt et al. (1980)

$\mathrm{PP}\left(\mu \mathrm{g} \mathrm{C}^{-1} \mathrm{~h}^{-1}\right)=P_{\mathrm{m}}\left[1-\exp \left(\frac{-\alpha E_{\mathrm{PAR}}}{P_{\mathrm{m}}}\right)\right]$

where PP is the primary production, $P_{\mathrm{m}}\left(\mu \mathrm{g} \mathrm{C}^{-1} \mathrm{~h}^{-1}\right)$ is the maximum photosynthetic rate at light saturation, $\alpha$ ( $\mu \mathrm{g} \mathrm{C} \mathrm{m}^{2} \mathrm{~s} \mu \mathrm{mol}$ photons ${ }^{-1} \mathrm{l}^{-1} \mathrm{~h}^{-1}$ ) is the initial slope of the light curve, and $E_{\mathrm{PAR}}\left(\mu \mathrm{mol}\right.$ photons $\left.\mathrm{m}^{-2} \mathrm{~s}^{-1}\right)$ is the laboratory irradiance. The photoadaptation index, $E_{\mathrm{k}}$ ( $\mu$ mol photons $\mathrm{m}^{-2} \mathrm{~s}^{-1}$ ), was calculated as $P_{\mathrm{m}} / \alpha$.

In situ down-welling irradiance was measured at ground level (Kipp \& Zonen pyrometer, CM21, spectrum range of $305-2,800 \mathrm{~nm}$ ) once every $5 \mathrm{~min}$, and hourly averages were provided by Asiaq (Greenland Survey). Hourly downwelling irradiance was converted into hourly 
photosynthetically active radiation (PAR; light spectrum $300-700 \mathrm{~nm})$ after intercalibration $\left(R^{2}=0.99, P<0.001\right.$, $n=133$ ) with a Li-Cor quantum 2 pi sensor connected to a LI-1400 data logger (Li-Cor Biosciences ${ }^{\circledR}$ ). The in situ hourly PAR irradiance was calculated at different depths, depending on sea ice and snow thickness, using the attenuation coefficients measured during the sea ice season.

In situ primary production was calculated for each hour at different sea ice depths using hourly in situ PAR irradiance (Eq. 1). Total daily ( $24 \mathrm{~h})$ in situ primary production was calculated as the sum of hourly in situ primary production for each depth. The depth-integrated net primary production was calculated using trapezoid integration.

Light attenuation of the sea ice samples was measured with a Li-Cor quantum 2 pi sensor connected to a LI-1400 data logger (Li-Cor Biosciences ${ }^{\circledR}$ ) in a dark, temperatureregulated room (at in situ temperatures to avoid brine loss) using a fiber lamp with a spectrum close to natural sunlight $(15 \mathrm{~V}, 150 \mathrm{~W}$, fiber-optic tungsten-halogen bulb). The sensor was placed under the sea ice section and the fiber lamp was placed above. Light attenuation was measured in this way for each sea ice section. We assume depth-independent attenuation in the sea ice. To measure light attenuation of the snow cover, we gently removed the snow and placed the sensor on the ice surface and then we placed the snow on top of the sensor. Thus, down-welling irradiance was measured directly above and below the snow (Søgaard et al. 2010).

The bacterial production procedures employed (i.e., 17 February, 11 March, 8 April, and 1 May) have been described by Søgaard et al. (2010), except those between 13 and 16 March, when the measurements were made using an ice-crushing method described by Kaartokallio (2004) and Kaartokallio et al. (2007). The two methods used for bacterial production measurements yield comparable results (the mean values from March using the ice-crushing method were $2.4 \mu \mathrm{g} \mathrm{C}^{-1} \mathrm{day}^{-1}$ and the mean values from April using the melting sea ice approach were $\left.2.5 \mu \mathrm{g} \mathrm{C}^{-1} \mathrm{day}^{-1}\right)$.

Bacterial production in melted sea ice samples was determined by measuring the incorporation of $\left[{ }^{3} \mathrm{H}\right]$ thymidine into DNA. Triplicate samples $($ volume $=0.01 \mathrm{~L}$ ) were incubated in darkness at $3 \pm 1{ }^{\circ} \mathrm{C}$ with $10 \mathrm{nmol} l^{-1}$ of labeled $\left[{ }^{3} \mathrm{H}\right]$ thymidine (New England Nuclear ${ }^{\circledR}$, specific activity $10.1 \mathrm{Ci} \mathrm{mmol}^{-1}$ ). Trichloroacetic acid (TCA)treated controls were made to measure the abiotic adsorption. At the end of incubation period $(T=6 \mathrm{~h}), 1 \mathrm{ml}$ of $50 \%$ cold TCA was added to all the samples. The samples were filtered and counted using a liquid scintillation analyzer (TricCarb 2800, PerkinElmer ${ }^{\circledR}$ ).

For the ice-crushing method, samples were prepared by crushing each intact 5 to $10 \mathrm{~cm}$ ice core section, first using a spike tool, and then grinding ice chunks in an electrical ice cube crusher. Approximately $10 \mathrm{ml}$ of crushed ice was placed in a scintillation vial and weighed. To ensure even distribution of labeled substrate, $2-4 \mathrm{ml}$ of sterile-filtered $\left(0.2 \mu \mathrm{m}\right.$ minisart filters, Sartorius $\left.{ }^{\circledR}\right)$ seawater was added to the scintillation vials. All ice-processing work was done in a cold on-deck laboratory at near-zero temperature. Two aliquots and a formaldehyde-killed absorption blank were amended with [methyl-3H] thymidine (New England Nuclear $^{\circledR}$; specific activity $20 \mathrm{Ci} \mathrm{mmol}^{-1}$ ). Concentrations of $20 \mathrm{nmol} 1^{-1}$ for thymidine were used for all samples. Samples were incubated in the dark at $-0.2{ }^{\circ} \mathrm{C}$ in a seawater/ice-crush bath for 17-18 $\mathrm{h}$ and incubation stopped with the addition of $200 \mu \mathrm{l}$ of $37 \%$ sterile-filtered formaldehyde. Samples were processed using standard coldTCA extraction and filtration procedure (using Advantec ${ }^{\circledR}$ MFS $0.2 \mu \mathrm{m}$ MCE filters). A Wallac Win-Spectral 1414 counter (PerkinElmer ${ }^{\circledR}$ ) and InstaGel (PerkinElmer ${ }^{\circledR}$ ) cocktail were used for scintillation counting.

For both methods, the bacterial carbon production was calculated, using the conversion factors presented in Smith and Clement (1990).

Bacterial carbon demand (BCD) for growth was calculated as:

$\mathrm{BCD}\left(\mu \mathrm{g} \mathrm{C} 1^{-1} \mathrm{~h}^{-1}\right)=\frac{\mathrm{BP}}{\mathrm{BGE}}$

where BP is the bacteria production and BGE is a bacterial growth efficiency estimate of 0.5 measured in polar oceans (Rivkin and Legendre 2001).

To investigate the temporal distribution of $\mathrm{TCO}_{2}$ and $\mathrm{TA}$, an additional sea ice core was collected on each sampling occasion. The core was cut into $12-\mathrm{cm}$ sections and placed in laminated transparent NEN/PE plastic bags (Hansen et al. 2000) fitted with a gas-tight Tygon tube and a valve for sampling. These sections were brought back to the laboratory cold room $\left(3 \pm 1{ }^{\circ} \mathrm{C}\right)$. Cold $\left(1^{\circ} \mathrm{C}\right)$ deionized water of known weight and $\mathrm{TA}$ and $\mathrm{TCO}_{2}$ concentration was added $(10-30 \mathrm{ml})$ to each NEN/PE bag (Hansen et al. 2000). The bags were closed, and excess air quickly extracted through the valve. Then, the ice was melted $(<48 \mathrm{~h})$ in the dark. Gas bubbles released from the melting sea ice were transferred to tubes $(12 \mathrm{ml}$ Exetainer $\left.{ }^{\circledR}\right)$. Sea ice meltwater was likewise transferred to similar tubes containing $20 \mu \mathrm{HgCl}_{2}$ (5\% w/v saturated solution; Rysgaard and Glud 2004). Standard methods of analysis were used: $\mathrm{TCO}_{2}$ concentrations were measured on a coulometer, TA by potentiometric titration (Haraldsson et al. 1997), and gaseous $\mathrm{O}_{2}, \mathrm{CO}_{2}, \mathrm{~N}_{2}$ by gas chromatography (SRI 8610C; FID/TCD detector; Lee et al. 2005).

A Wilcoxon rank sum test was used to test whether $\mathrm{CaCO}_{3}$ concentration was significantly differently distributed within the sea ice. We applied a significance level of $95 \%$. 
Following the bulk determination of $\mathrm{TCO}_{2}$ and TA, the bulk $p \mathrm{CO}_{2}$ and $\mathrm{pH}$ (on the total scale) were computed using the temperature and salinity conditions in the field and a standard set of carbonate system equations (See Rysgaard et al. 2013), excluding nutrients, with the CO2SYS program of Lewis and Wallace (2012). We used the equilibrium constants of Mehrbach et al. (1973), refitted by Dickson and Millero (1987, 1989). We assumed a conservative behavior of $\mathrm{CO}_{2}$ dissociation constants at subzero temperatures since Marion (2001) and Delille et al. (2007) suggested that a thermodynamic constant relevant for the carbonate system can be assumed to be valid at subzero temperatures.

\section{Results}

Figure 1 shows a map of the investigated sea ice area with the different sampling stations in Kapisigdlit, SW Greenland (Fig. 1).

The air temperature during the study period ranged from $-17{ }^{\circ} \mathrm{C}$ in February to $+16^{\circ} \mathrm{C}$ in May just before the sea ice break-up (Fig. 2). Temperatures within the snow and sea ice varied from $-6.0 \pm 0.1$ to $0 \pm 0.02{ }^{\circ} \mathrm{C}$, with minimum temperatures measured in February and March, followed by a gradual increase to maximum values in late April (Fig. 3a).

The bulk salinity of the sea ice samples varied from 1.7 to 6 (Fig. 3b). The brine volume varied from 5 to $32 \%$ at the top of the sea ice and from 12 to $40 \%$ at the bottom of the sea ice (Fig. 3c), an indication that the ice was permeable for most of the study (Golden et al. 1998). In April, when air temperatures varied between -2 and $+16{ }^{\circ} \mathrm{C}$, the ice began to melt, which resulted in high relative brine volumes and low bulk salinities (Fig. 3b, c).

Spatial variability

Moran's I (Table 1) was used to estimate the spatial autocorrelation within the datasets collected for the two

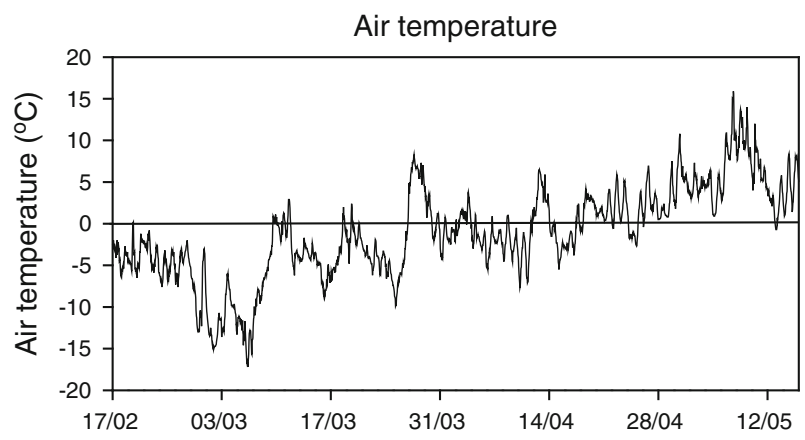

Fig. 2 Meteorological data on air temperature $\left({ }^{\circ} \mathrm{C}\right)$ at the Asiaq meteorological station in Kapisigdlit (a) Sea ice and snow temperature $\left[{ }^{\circ} \mathrm{C}\right]$

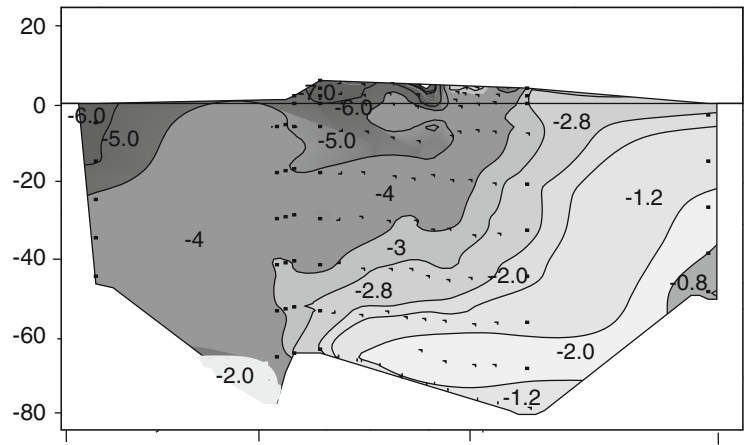

(b) Bulk salinity

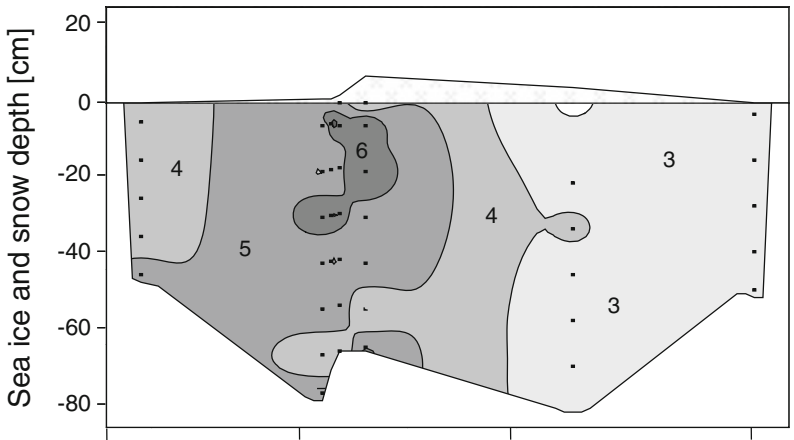

(c) Relative brine volume [\%]

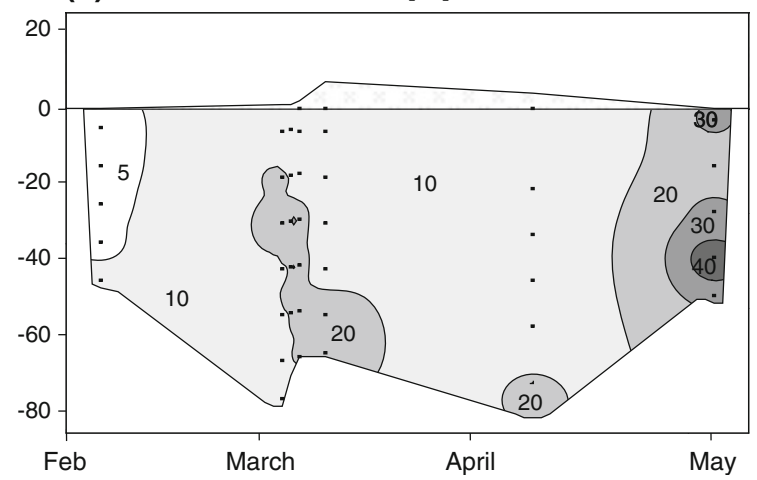

Fig. 3 Temporal development in (a) sea ice and snow temperature $\left[{ }^{\circ} \mathrm{C}\right]$ N.B. The temperature data collected from retrieved ice cores are supplemented by thermistor string data from 11 March until 8 April, (b) bulk salinity, (c) relative brine volume fraction [\%]. The black dots represent triplicate measurements

transect samplings in March and April. All parameters had a random spatial distribution pattern with no apparent patches, indicating that the distribution of the parameters investigated was highly heterogeneous on the scale of meters to hundreds of meters (Table 1).

Despite this heterogeneity, there was evidence of a correlation between several parameters: $\mathrm{CaCO}_{3}$ had significant correlation with $\mathrm{PO}_{4}{ }^{3-}$, bulk salinity, $\mathrm{Si}(\mathrm{OH})_{4}$ and $\mathrm{NO}_{3}{ }^{-} \cdot \mathrm{CaCO}_{3}$ and DON were significantly correlated (negative) only during the second sampling. There was no 
Table 1 Moran's I as a function of distance class (m) between sites for $\mathrm{CaCO}_{3}$, bulk salinity, DOC, DON, $\mathrm{NH}_{4}{ }^{+}, \mathrm{NO}_{2}{ }^{-}, \mathrm{NO}_{3}{ }^{-}$, $\mathrm{Si}(\mathrm{OH})_{4}$ and $\mathrm{PO}_{4}{ }^{3-}$ in snow (S), top sea ice $(\mathrm{T})$ and bottom sea ice (B). First sampling period was on March 11 and second sampling period was on April 8, 2010. Positive (+) indicates positive autocorrelation (correlation) or negative (-) negative autocorrelation (dispersion). A zero value indicates a random spatial pattern

\begin{tabular}{|c|c|c|c|c|c|c|c|c|c|c|c|c|c|c|c|c|c|c|c|c|c|c|c|c|}
\hline \multicolumn{25}{|l|}{ First sampling } \\
\hline \multirow[t]{2}{*}{ Distance class (m) } & \multicolumn{3}{|c|}{$\mathrm{CaCO}_{3}$} & \multicolumn{3}{|c|}{ Bulk salinity } & \multicolumn{3}{|c|}{ DOC } & \multicolumn{3}{|c|}{ DON } & \multicolumn{3}{|c|}{$\mathrm{NH}_{4}^{+}$} & \multicolumn{3}{|c|}{$\mathrm{NO}_{2}^{-}$} & \multicolumn{3}{|c|}{$\mathrm{NO}_{3}{ }^{-}$} & \multicolumn{3}{|c|}{$\mathrm{Si}(\mathrm{OH})_{4}$} \\
\hline & $\mathrm{S}$ & $\mathrm{T}$ & B & S & $\mathrm{T}$ & B & $\mathrm{S}$ & $\mathrm{T}$ & B & $\mathrm{S}$ & $\mathrm{T}$ & B & S & $\mathrm{T}$ & B & $\mathrm{S}$ & $\mathrm{T}$ & B & $\mathrm{S}$ & $\mathrm{T}$ & B & $S$ & $\mathrm{~T}$ & B \\
\hline 0.25 & 0 & 0 & 0 & 0 & 0 & 0 & 0 & 0 & 0 & 0 & 0 & 0 & 0 & 0 & 0 & 0 & 0 & 0 & 0 & 0 & 0 & 0 & 0 & 0 \\
\hline 0.5 & 0 & 0 & 0 & 0 & - & 0 & 0 & 0 & 0 & 0 & 0 & 0 & 0 & 0 & 0 & 0 & 0 & 0 & 0 & 0 & 0 & 0 & 0 & 0 \\
\hline 1.0 & 0 & 0 & 0 & 0 & - & - & 0 & 0 & 0 & 0 & - & 0 & 0 & 0 & 0 & 0 & 0 & 0 & 0 & - & - & - & 0 & 0 \\
\hline 2.5 & 0 & 0 & 0 & - & 0 & 0 & 0 & 0 & 0 & + & + & 0 & - & 0 & 0 & - & + & + & + & + & 0 & 0 & - & 0 \\
\hline 5.0 & 0 & 0 & 0 & 0 & - & 0 & 0 & 0 & 0 & 0 & - & 0 & 0 & 0 & 0 & 0 & 0 & 0 & 0 & 0 & 0 & - & 0 & 0 \\
\hline 10 & 0 & 0 & 0 & - & 0 & 0 & 0 & 0 & 0 & 0 & 0 & 0 & 0 & 0 & 0 & 0 & 0 & 0 & 0 & 0 & 0 & 0 & 0 & 0 \\
\hline 50 & 0 & 0 & 0 & 0 & 0 & 0 & 0 & 0 & 0 & 0 & 0 & 0 & - & 0 & 0 & 0 & - & 0 & 0 & 0 & 0 & 0 & 0 & 0 \\
\hline 100 & 0 & 0 & 0 & 0 & 0 & 0 & 0 & 0 & 0 & - & 0 & - & 0 & 0 & 0 & 0 & 0 & 0 & 0 & 0 & 0 & 0 & 0 & 0 \\
\hline 200 & 0 & 0 & 0 & 0 & 0 & 0 & 0 & 0 & 0 & - & 0 & 0 & 0 & 0 & 0 & 0 & 0 & 0 & 0 & 0 & 0 & 0 & - & 0 \\
\hline 250 & - & 0 & 0 & 0 & + & 0 & 0 & 0 & 0 & - & 0 & 0 & + & 0 & 0 & 0 & 0 & 0 & - & 0 & 0 & 0 & 0 & 0 \\
\hline$>250$ & - & 0 & 0 & 0 & 0 & 0 & 0 & 0 & 0 & 0 & 0 & 0 & 0 & 0 & 0 & 0 & 0 & 0 & 0 & 0 & 0 & 0 & 0 & 0 \\
\hline
\end{tabular}

Second sampling

\begin{tabular}{|c|c|c|c|c|c|c|c|c|c|c|c|c|c|c|c|c|c|c|c|c|c|c|c|c|c|c|c|}
\hline \multirow[t]{2}{*}{ Distance class (m) } & \multicolumn{3}{|c|}{$\mathrm{CaCO}_{3}$} & \multicolumn{3}{|c|}{ Bulk salinity } & \multicolumn{3}{|c|}{ DOC } & \multicolumn{3}{|c|}{ DON } & \multicolumn{3}{|c|}{$\mathrm{NH}_{4}+$} & \multicolumn{3}{|c|}{$\mathrm{NO}_{2}^{-}$} & \multicolumn{3}{|c|}{$\mathrm{NO}_{3}^{-}$} & \multicolumn{3}{|c|}{$\mathrm{Si}(\mathrm{OH})_{4}$} & \multicolumn{3}{|c|}{$\mathrm{PO}_{4}{ }^{3-}$} \\
\hline & S & $\mathrm{T}$ & B & $\mathrm{S}$ & $\mathrm{T}$ & B & $\mathrm{S}$ & $\mathrm{T}$ & B & $\mathrm{S}$ & $\mathrm{T}$ & B & $\mathrm{S}$ & $\mathrm{T}$ & B & S & $\mathrm{T}$ & B & $\mathrm{S}$ & $\mathrm{T}$ & B & $\mathrm{S}$ & $\mathrm{T}$ & B & $\mathrm{S}$ & $\mathrm{T}$ & \\
\hline 0.25 & 0 & 0 & 0 & 0 & 0 & 0 & 0 & 0 & 0 & 0 & 0 & 0 & 0 & 0 & 0 & 0 & 0 & - & 0 & 0 & 0 & 0 & 0 & 0 & 0 & 0 & \\
\hline 0.5 & 0 & 0 & 0 & 0 & 0 & 0 & 0 & - & 0 & 0 & - & 0 & 0 & 0 & 0 & 0 & 0 & 0 & 0 & 0 & 0 & 0 & 0 & 0 & 0 & 0 & \\
\hline 1.0 & 0 & 0 & 0 & 0 & - & 0 & 0 & 0 & 0 & 0 & 0 & 0 & 0 & 0 & 0 & 0 & - & - & 0 & 0 & - & 0 & 0 & 0 & 0 & 0 & \\
\hline 2.5 & + & - & 0 & + & + & + & 0 & + & 0 & - & 0 & 0 & - & 0 & + & 0 & 0 & 0 & + & 0 & 0 & 0 & 0 & 0 & 0 & 0 & \\
\hline 5.0 & 0 & 0 & 0 & 0 & 0 & 0 & 0 & 0 & 0 & 0 & 0 & 0 & 0 & 0 & 0 & 0 & 0 & - & - & 0 & 0 & - & 0 & 0 & + & 0 & \\
\hline 10 & 0 & 0 & 0 & 0 & 0 & 0 & 0 & 0 & 0 & 0 & 0 & 0 & 0 & 0 & 0 & 0 & + & 0 & 0 & 0 & 0 & 0 & 0 & 0 & 0 & 0 & \\
\hline 50 & 0 & 0 & 0 & 0 & 0 & 0 & 0 & 0 & 0 & 0 & 0 & 0 & 0 & 0 & 0 & 0 & - & 0 & 0 & 0 & 0 & 0 & 0 & 0 & 0 & 0 & \\
\hline 100 & 0 & 0 & 0 & 0 & 0 & 0 & 0 & - & 0 & 0 & 0 & 0 & 0 & - & 0 & 0 & 0 & 0 & 0 & 0 & 0 & 0 & 0 & 0 & 0 & - & \\
\hline 200 & 0 & 0 & 0 & 0 & 0 & 0 & 0 & 0 & 0 & 0 & 0 & 0 & 0 & 0 & 0 & 0 & 0 & 0 & 0 & 0 & 0 & 0 & 0 & 0 & 0 & 0 & \\
\hline 250 & 0 & 0 & - & 0 & 0 & 0 & 0 & + & 0 & 0 & 0 & 0 & 0 & 0 & 0 & 0 & 0 & + & 0 & - & - & 0 & 0 & 0 & 0 & 0 & \\
\hline$>250$ & 0 & 0 & 0 & 0 & 0 & 0 & 0 & 0 & 0 & 0 & 0 & 0 & 0 & 0 & 0 & 0 & 0 & 0 & 0 & 0 & 0 & 0 & 0 & 0 & 0 & 0 & \\
\hline
\end{tabular}

correlation between $\mathrm{CaCO}_{3}$ and $\mathrm{DOC}, \mathrm{NH}_{4}{ }^{+}, \mathrm{NO}_{2}{ }^{-}$, and temperature (Table 2).

A GLM where depth (vertical), time, and position (horizontal) as explanatory variables is used to test whether there was a significant effect on several dependent variables: $\mathrm{CaCO}_{3}$, bulk salinity, DOC, and DON. The GLM test was applied on the datasets collected for the two transect samplings in March and April. There was a significant effect of depth for all the parameters. The significant effect of depth was largely dependent on the time of sampling for $\mathrm{CaCO}_{3}\left(F_{5,261}=15.9784, P<0.001\right)$, bulk salinity $\left(F_{5,248}=5.6322 P<0.001\right)$, and DON $\left(F_{5,239}=\right.$ $3.6861 P<0.001$ ) (data not shown). Furthermore, when the two studies in March and April were compared, a significant effect of time was found for bulk salinity, DOC, and DON (Table 3). No significant effect of position (horizontal) was found for $\mathrm{CaCO}_{3}$, bulk salinity, and DON (Table 3).

\section{Temporal distribution}

In the temporal survey, there were no vertical differences in $\mathrm{TCO}_{2}$ and TA (Fig. 4), although the concentrations of $\mathrm{TCO}_{2}$ and TA decreased with time (Fig. 4). The highest $\mathrm{TCO}_{2}$ and TA concentrations were measured in February $\left(293 \pm 6.1\right.$ and $410 \pm 40 \mu \mathrm{mol} \mathrm{kg}{ }^{-1}$ in melted sea ice), which decreased to $181 \pm 1.3$ and $190 \pm 1.2 \mu \mathrm{mol} \mathrm{kg}{ }^{-1}$ in melted sea ice in the beginning of May, respectively (Fig. 4). However, high concentrations of TA and $\mathrm{TCO}_{2}$ were also measured in April (Fig. 4). No small-scale variability was observed for $\mathrm{TCO}_{2}$ and TA concentrations. 
Table 2 Pairwise comparison of $\mathrm{CaCO}_{3}$, bulk salinity, temperature, DOC, DON, $\mathrm{NH}_{4}{ }^{+}, \mathrm{NO}_{2}{ }^{-}, \mathrm{NO}_{3}{ }^{-}, \mathrm{Si}(\mathrm{OH})_{4}$ and $\mathrm{PO}_{4}{ }^{3-}$. (-) indicates significantly negative $(-)$ and $(+)$ indicates significantly positive $(+)$ correlated variables (Pearsons) at a $5 \%$ significance level. First sampling period was in March and second sampling period in April 2010

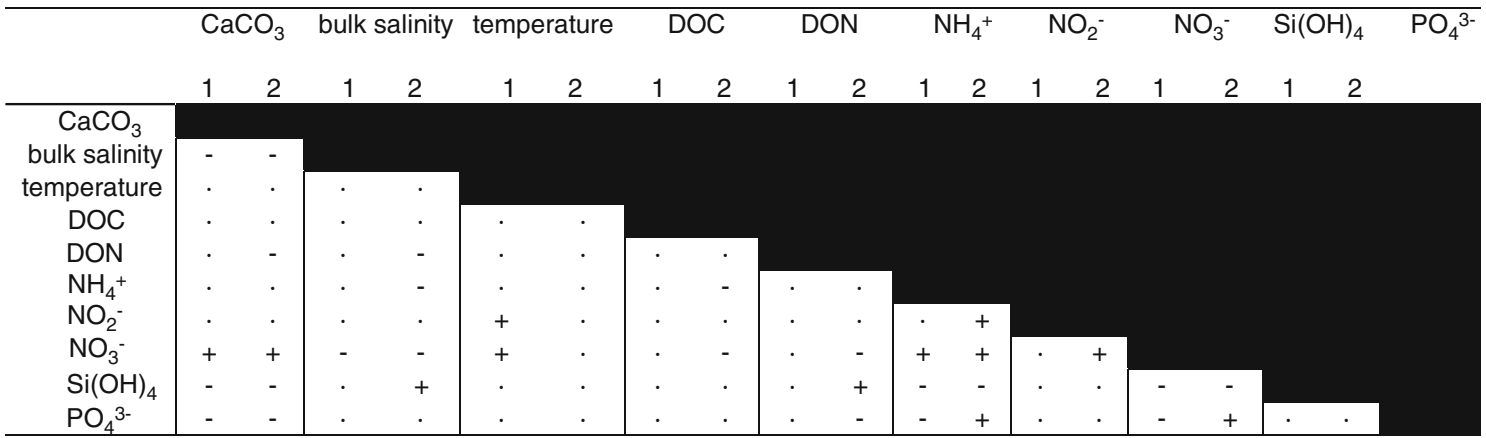

In the water column, the highest $\mathrm{TCO}_{2}$ concentration, of $2,101 \pm 7.7 \mu \mathrm{mol} \mathrm{kg}^{-1}$, was measured in February, which decreased to $2,085 \pm 27 \mu \mathrm{mol} \mathrm{kg}{ }^{-1}$ in May (Fig. 4). The highest TA concentration of 2,253 $\pm 2.5 \mu \mathrm{mol} \mathrm{kg}^{-1}$ was measured in May and the lowest of 2,220 $\pm 2.2 \mu \mathrm{mol} \mathrm{kg}^{-1}$ in March (Fig. 4).

The average TA: $\mathrm{TCO}_{2}$ ratio within the sea ice was $>1$ during February (average 1.25) and March (average 1.20), and higher than that in the water column (Fig. 4). The highest $\mathrm{TA}: \mathrm{TCO}_{2}$ ratio (1.75) was calculated for the uppermost horizons of the sea ice in April. In April, the average ratio was 1.32 , while the value in the beginning of May was 1.1.

The $\mathrm{CaCO}_{3}$ concentrations varied vertically within the ice cores: in February the highest concentration of $2.4 \pm 0.4 \mu \mathrm{mol} \mathrm{CaCO}_{3} \mathrm{l}^{-1}$ was measured in the upper most layer of the sea ice (Wilcoxon rank sum test; $P<0.05$; Fig. 5). Conversely, just before ice break-up in early May, the highest $\mathrm{CaCO}_{3}$ concentration of $4.4 \pm 0.1 \mu \mathrm{mol} \mathrm{Ca}$ $\mathrm{CO}_{3} \mathrm{l}^{-1}$ was measured in the lowermost ice horizon (Wilcoxon rank sum test; $P<0.05$; Fig. 5). In March and April, $\mathrm{CaCO}_{3}$ was evenly distributed within the sea ice with an average concentration of $1.8 \pm 0.40 \mu \mathrm{mol} \mathrm{CaCO} \mathrm{Cl}^{-1}$ in March and $2.0 \pm 0.30 \mu \mathrm{mol} \mathrm{CaCO}_{3} 1^{-1}$ in April (Wilcoxon rank sum test; $P>0.05$ ). No small-scale variability was observed for $\mathrm{CaCO}_{3}$ concentration in the sea ice (Fig. 5). $\mathrm{CaCO}_{3}$ concentrations in the snow decreased throughout the sea ice season: from $5.2 \pm 1.5 \mu \mathrm{mol} \mathrm{CaCO}_{3} \mathrm{l}^{-1}$ in February to $3.0 \pm 1.5 \mu \mathrm{mol} \mathrm{CaCO}_{3} \mathrm{I}^{-1}$ in April (Fig. 5). Sediment traps were deployed under the sea ice during the study period but no $\mathrm{CaCO}_{3}$ crystals were found (data not shown).

The DOC concentrations increased over time with a maximum concentration of $160 \mu \mathrm{mol}^{-1}$ being measured in May in the bottommost layer of the ice (Fig. 6). DON concentrations did not vary vertically within the sea ice during winter. However, in April and May, when the sea ice began to melt, the DON concentrations increased, and maximum DON values of $15 \mu \mathrm{mol} \mathrm{l}^{-1}$ were measured in the bottommost part of the sea ice (Fig. 6). The DOC:DON ratios ranged from 5 to 20 (average 12).

The highest volume-specific primary production (bulk) of $25 \mu \mathrm{g} \mathrm{C} ~^{-1}$ day $^{-1}$ was measured in March in the bottom of the sea ice (Fig. 6). Bacterial carbon demand varied vertically within the sea ice, with maximum values measured in the top and bottom section of the sea ice in March and May (Fig. 6). In February and April, the maximum $\mathrm{BCD}$ was measured in the internal sea ice layers. The highest $\mathrm{BCD}$ of $5.8 \mu \mathrm{g} \mathrm{C}^{-1}$ day $^{-1}$ was estimated in the bottommost sections of the sea ice in March.

Bulk nutrient concentrations for each sampling date were plotted as a function of bulk salinity and compared with the expected dilution line (Clarke and Ackley 1984). To calculate the dilution line, we used the average nutrient concentration and salinity measured at 17 February, 11

Table 3 Results from a GLM model where depth, time, and position as explanatory variables were used to test whether there was a significant effect on several dependent variables: $\mathrm{CaCO}_{3}$, bulk salinity, DOC, and DON

\begin{tabular}{llllll}
\hline Variable & Position & & Time & Depth \\
\hline $\mathrm{CaCO}_{3}$ & $F_{24,261}=1.2685$ & $P=0.19$ & $F_{1,261}=2.6087$ & $P=0.11$ & $F_{5,261}=53.7673$ \\
Bulk salinity & $F_{24,248}=0.8054$ & $P=0.73$ & $F_{1,248}=18.4728$ & $P<0.001$ & $F_{5,248}=14.2994$ \\
DOC & $F_{24,217}=2.13$ & $P<0.001$ & $F_{1,217}=224.6497$ & $P<0.001$ & $F_{5,217}=3.1986$ \\
DON & $F_{24,239}=0.5919$ & $P=0.94$ & $F_{1,239}=162.4025$ & $P<0.001$ & $F_{5,239}=6.6925$ \\
\hline
\end{tabular}



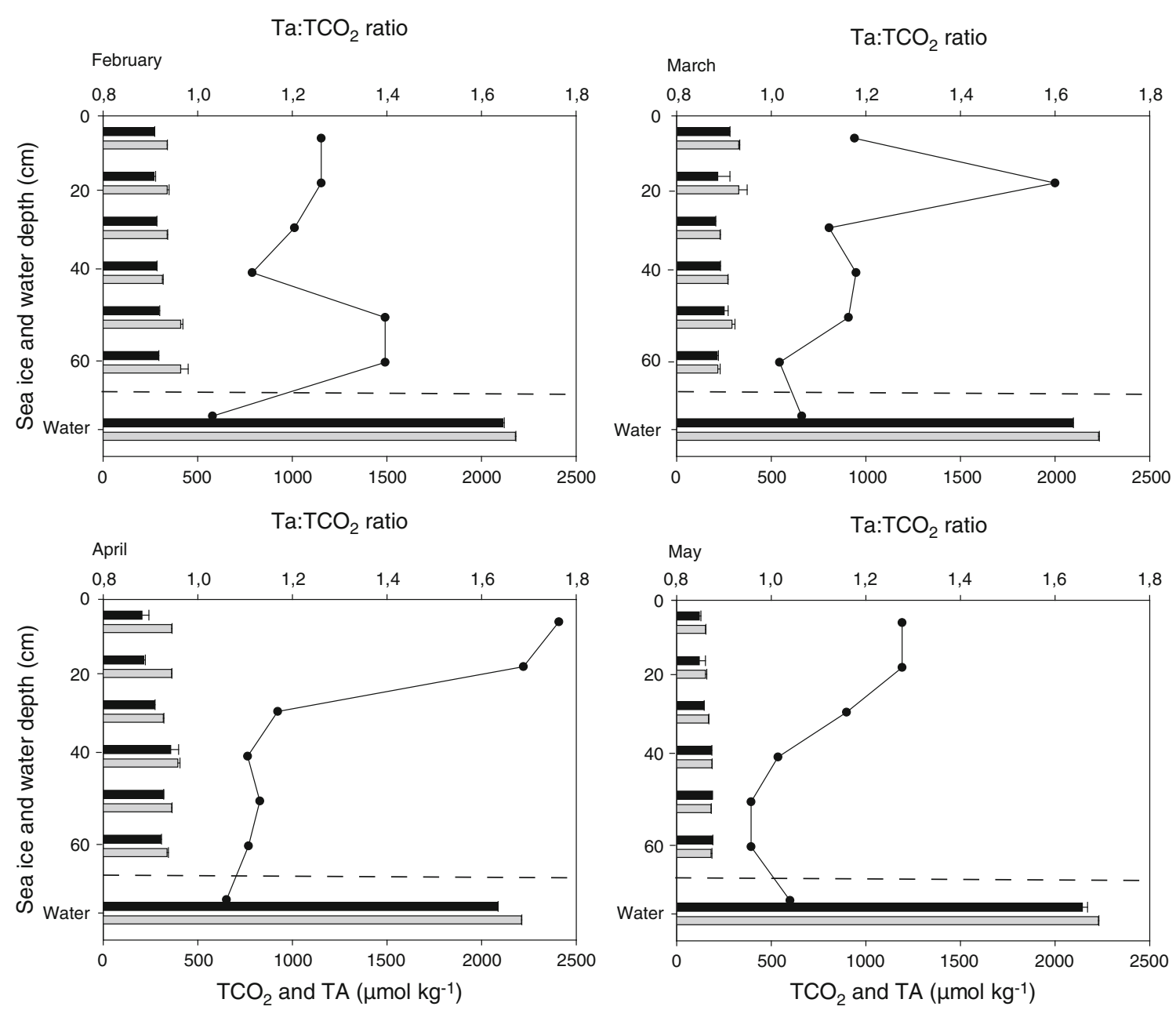

Fig. 4 Temporal development of the vertical concentration profiles of $\mathrm{TCO}_{2}$ (black bars) and TA (gray bars) and the $\mathrm{TA}: \mathrm{TCO}_{2}$ ratio (circles) in bulk melted sea ice during the 2010 sea ice season. Note

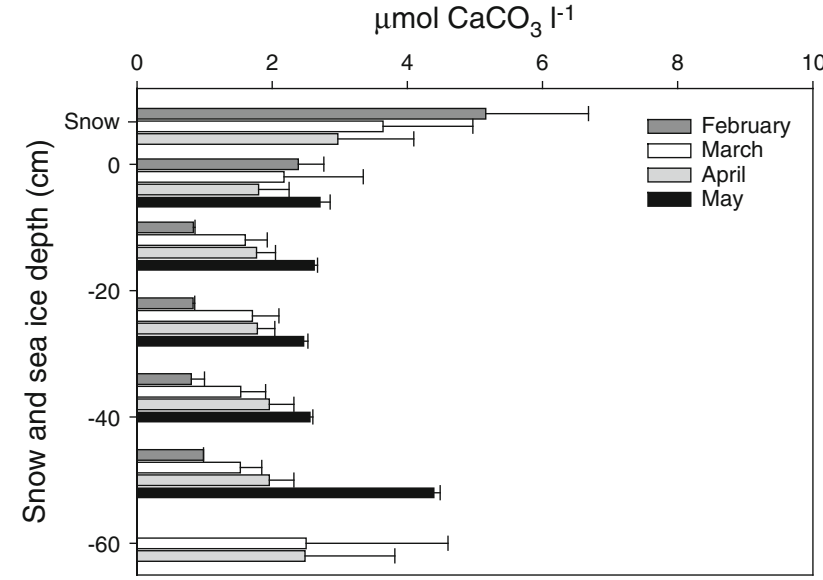

Fig. 5 Temporal development of the $\mathrm{CaCO}_{3}$ concentration [ $\mu$ mol $\mathrm{CaCO}_{3} 1^{-1}$ ] in bulk sea ice and snow in February, March, April, and May 2010 that $\mathrm{TCO}_{2}$ and TA below $60 \mathrm{~cm}$ are water column values. Horizontal dotted line represents the sea ice-water column interface. Data points represent treatment mean $\pm \mathrm{SE}(n=3)$

March, 8 April, and 1 May in the water column (i.e. $0-10 \mathrm{~m} ; \quad \mathrm{PO}_{4}{ }^{3-}=0.94 \mu \mathrm{mol} 1^{-1}, \quad \mathrm{Si}(\mathrm{OH})_{4}=7.0 \mu \mathrm{\omega}$ $\mathrm{mol} \mathrm{l} 1^{-1}, \quad \mathrm{NO}_{2}{ }^{-}+\mathrm{NO}_{3}{ }^{-}=8.6 \mu \mathrm{mol} \mathrm{l} 1^{-1}, \quad \mathrm{NH}_{4}{ }^{+}=0.28$ $\mu \mathrm{mol} \mathrm{1} 1^{-1}, \quad$ DOC $=62.6 \mu \mathrm{mol} \mathrm{1^{-1 }}, \quad$ DON $=1.2 \mu \mathrm{mol} \mathrm{l^{-1 }}$ and a average salinity of 33). If values are below the line, depletion of nutrients has taken place, and if above the dilution line production, or net-deposition, of the solute has occurred. Plots of salinity versus $\mathrm{PO}_{4}{ }^{3-}, \mathrm{Si}(\mathrm{OH})_{4}, \mathrm{NO}_{2}{ }^{-}+$ $\mathrm{NO}_{3}{ }^{-}, \mathrm{NH}_{4}{ }^{+}$, DOC, and DON in sea ice were generally all above the dilution line implying accumulation of nutrients and organic matter within the ice (Fig. 7a-f). However, depletion of $\mathrm{PO}_{4}{ }^{3-}$ was observed in February and March. Furthermore, $\mathrm{NO}_{2}{ }^{-}+\mathrm{NO}_{3}^{-}$was depleted in April and May.

There was a negative correlation between $\mathrm{PO}_{4}{ }^{3-}$ and $\mathrm{CaCO}_{3}$ and $\mathrm{Si}(\mathrm{OH})_{4}$ and $\mathrm{CaCO}_{3}$, while a positive correlation was observed between $\mathrm{NO}_{3}{ }^{-}$and $\mathrm{CaCO}_{3}$ (Table 2). 


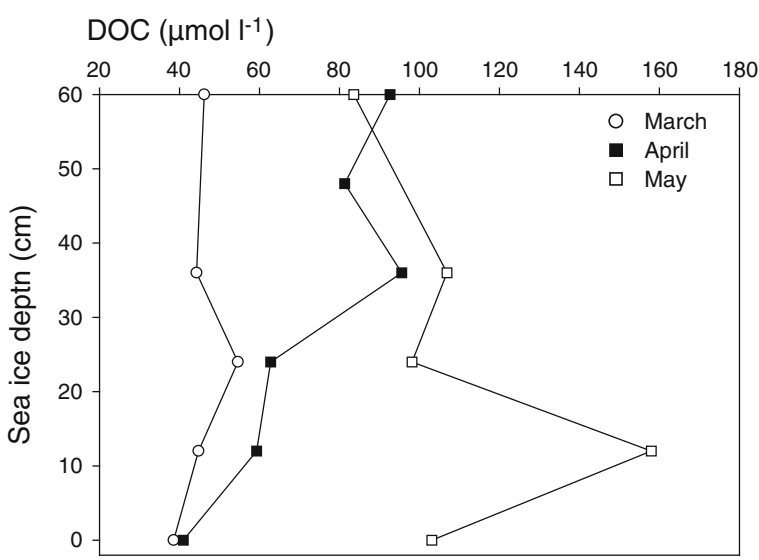

$\operatorname{DON}(\mu \mathrm{mol} \mathrm{l-1})$
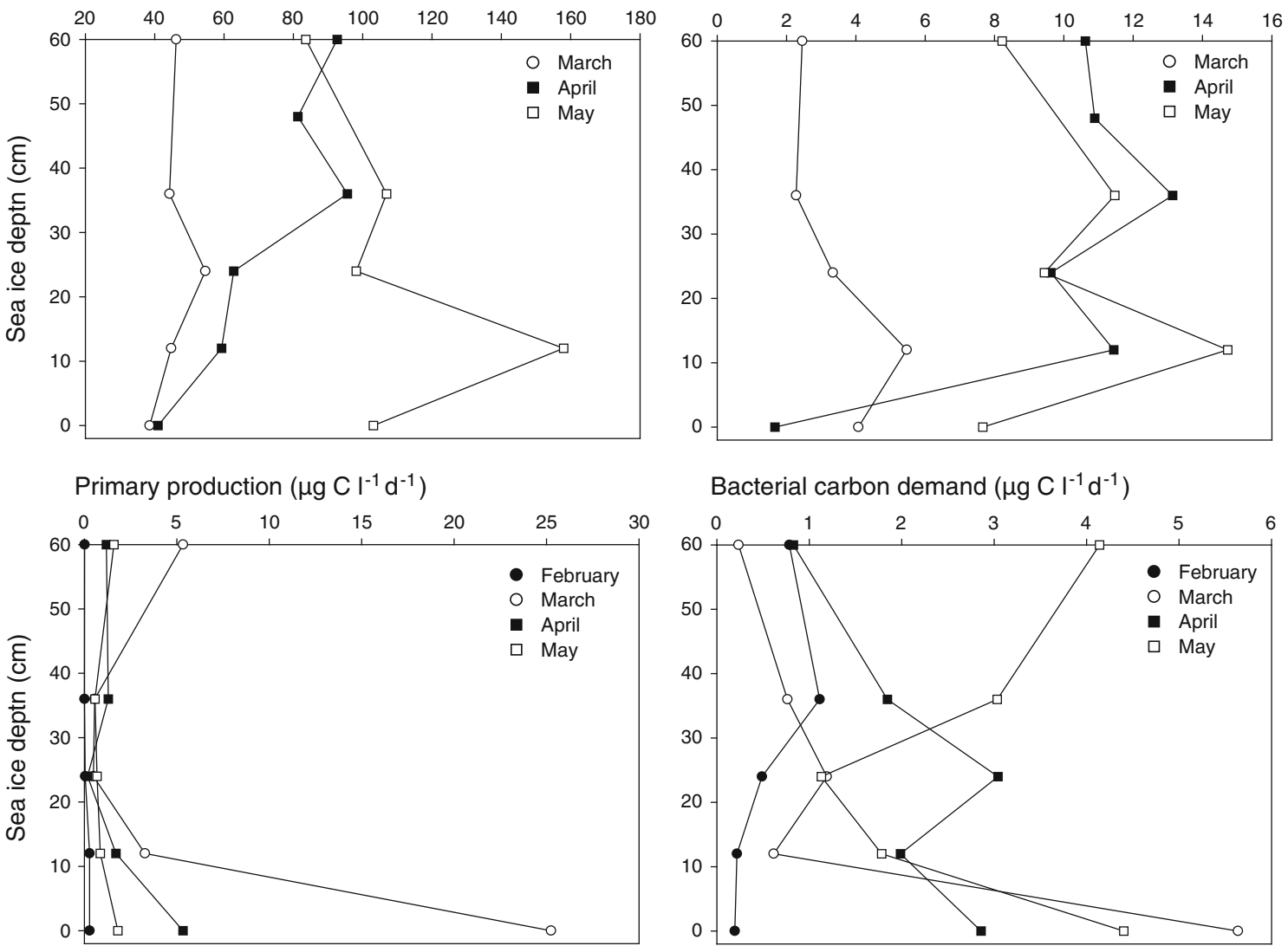

Fig. 6 Vertical profiles of DOC, DON, primary production, and bacterial carbon demand in bulk sea ice in February to May. N.B. there were no data available on the vertical profiles of DOC and DON in February

Figure 8 shows $n \mathrm{TA}$ and $n \mathrm{TCO}_{2}$ (TA and $\mathrm{TCO}_{2}$ value being normalized to a salinity of 33 to remove correlation to salinity) relationships in seawater samples and bulk ice samples. The different lines represent the theoretical effects of precipitation-dissolution of $\mathrm{CaCO}_{3}, \quad \mathrm{CO}_{2}$ release-uptake and photosynthesis-respiration on the ratio $n \mathrm{TCO}_{2}: n \mathrm{TA}$. The precipitation of $\mathrm{CaCO}_{3}$ decreases both $\mathrm{TCO}_{2}$ and TA in a ratio of 2:1. An exchange of $\mathrm{CO}_{2}$ has no impact on TA, while $\mathrm{TCO}_{2}$ will be affected. Biological activity has an almost negligible effect on TA, with a ratio TA: $\mathrm{TCO}_{2}=-0.16$ (Zeebe and Wolf-Gladrow 2001). Considering that sea ice was formed from seawater with a known TA: $\mathrm{TCO}_{2}$ ratio (Fig. 4), we are able to decipher which process took place in the ice: in February and March, the sea ice samples were aligned on the theoretical line for $\mathrm{CaCO}_{3}$ precipitation (Fig. 8). In April and May, the ice samples were well aligned (slope $0.75 ; R^{2}=0.86$ ) between the theoretical trend for $\mathrm{CaCO}_{3}$ precipitation/dissolution and the one for $\mathrm{CO}_{2}$ release/uptake (Fig. 8). In April two sea ice samples were aligned on the theoretical line for $\mathrm{CaCO}_{3}$ dissolution. This implies that both $\mathrm{CaCO}_{3}$ precipitation/dissolution and $\mathrm{CO}_{2}$ release/uptake had occurred in the ice.

\section{Discussion}

Biological activity

A maximum BCD of $5.8 \mu \mathrm{g} \mathrm{C}^{-1}$ day $^{-1}$ (Fig. 6) was estimated, which is low compared with maximum rates of $27 \mu \mathrm{g} \mathrm{C}^{-1}$ day $^{-1}$ estimated in the neighboring fjord Malene Bight in April 2008 (60 km to the SW from the present study site; Søgaard et al. 2010).

Pairwise correlations between primary production and BCD revealed significant positive relationships. Furthermore, accumulation of DOC was observed (Fig. 6e-f) as well as DOC/DON ratios ranging from 5 to 20 indicating a probable production of carbon-rich extracellular polymeric substances (EPS) by the sea ice algae and bacteria (Underwood et al. 2010; Krembs et al. 2011; Juhl et al. 2011). Correlation between primary production and BCD, high DOC/DON ratio and accumulation of DOC points to there being a low-quality substrate resulting in a low bacteria production. Previous studies have shown that EPS is a low-quality substrate for heterotrophic bacteria (Pomeroy and William 2001), which might explain the low BCD and the observed DOC accumulation (Fig. 6). However, several 

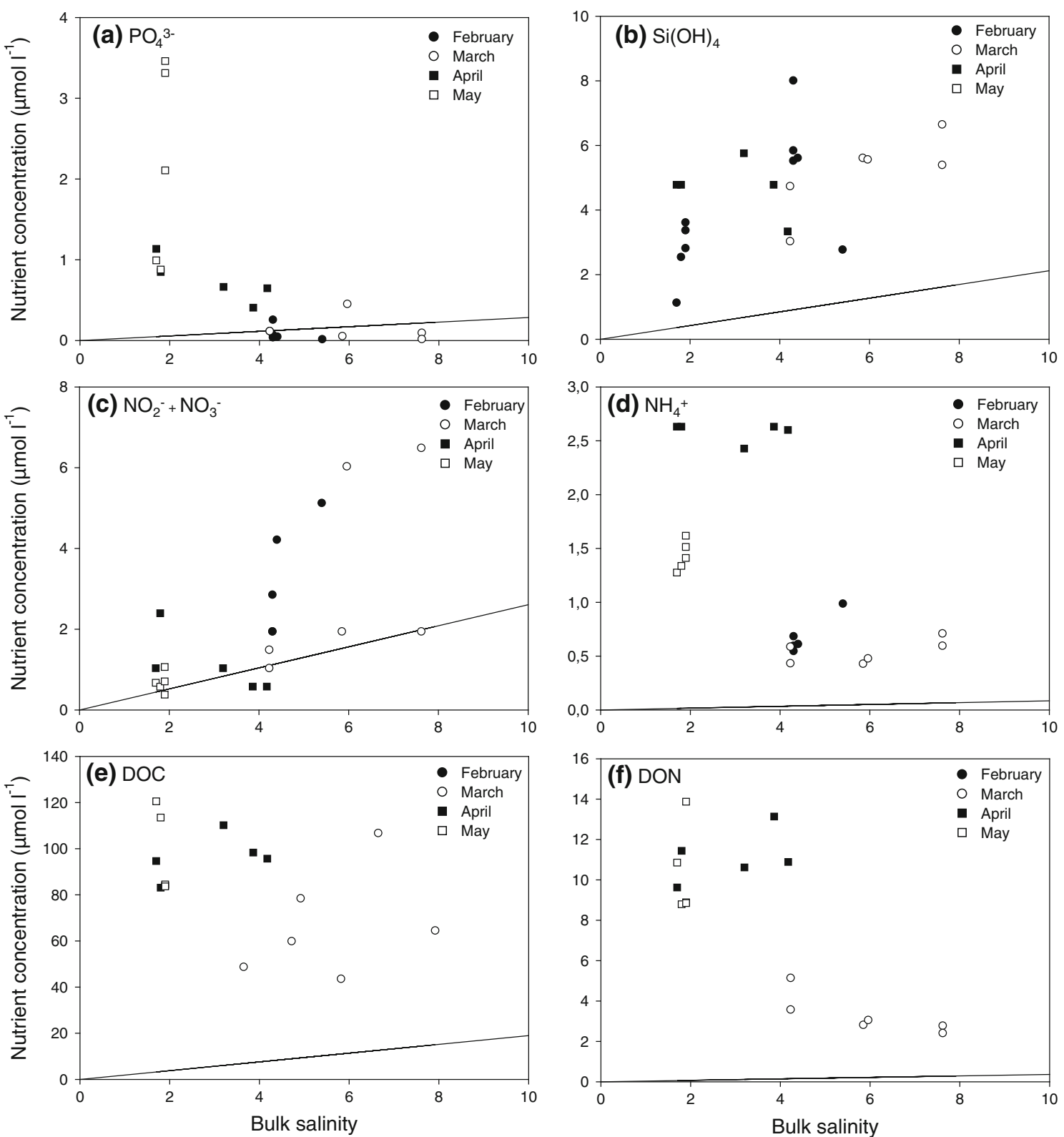

Fig. 7 Temporal development of (a) $\mathrm{PO}_{4}{ }^{3-}$, (b) $\mathrm{Si}(\mathrm{OH})_{4}, \quad$ (c) $\mathrm{NO}_{2}{ }^{-}+\mathrm{NO}_{3}{ }^{-}$, (d) $\mathrm{NH}_{4}^{+}$, e) DOC, and f) DON concentrations versus bulk salinity in sea ice from February to May. The solid line

indicates the expected dilution line predicted from salinity and nutrient concentrations in seawater $(0-10 \mathrm{~m}$, average salinity of 33 under the sea ice)

studies suggest the opposite that EPS serve as high-quality substrate for bacteria (e.g. Junge et al. 2004; Meiners et al. 2008).

Another explanation for the low BCD might be the value for bacterial growth efficiency used. We used a bacterial growth efficiency of 0.50 (Rivkin and Legendre 2001). However, growth efficiency is an inverse function of temperature, and small changes in temperature would influence growth efficiency ( $\sim 2.5 \%$ decrease in growth efficiency per $1{ }^{\circ} \mathrm{C}$ increase) and thereby the BCD (Rivkin and Legendre 2001). Using a lower growth efficiency $(<0.15$; e.g. Middelboe et al. 2012), the seasonal net

autotrophic sea ice would change to a net heterotrophic sea ice, which compares to result found by Long et al. (2011) in Kapisigdlit Bight in March 2010. Thereby the biological activity would not contribute to the atmospheric $\mathrm{CO}_{2}$ uptake at all. However, we believe the use of a growth efficiency of 0.50 to be most valid since it also agrees with the growth efficiency of 0.41 measured by Kuparinen et al. (2011) and Del Giorgio and Cole (1998).

The highest estimates of primary production (Fig. 6) were measured in the bottom ice horizons in March. Average rates of sea ice algal primary production during March (4.03 $\mathrm{mg} \mathrm{C} \mathrm{m}^{-2} \mathrm{day}^{-1}$ ) are at the lower end of the 


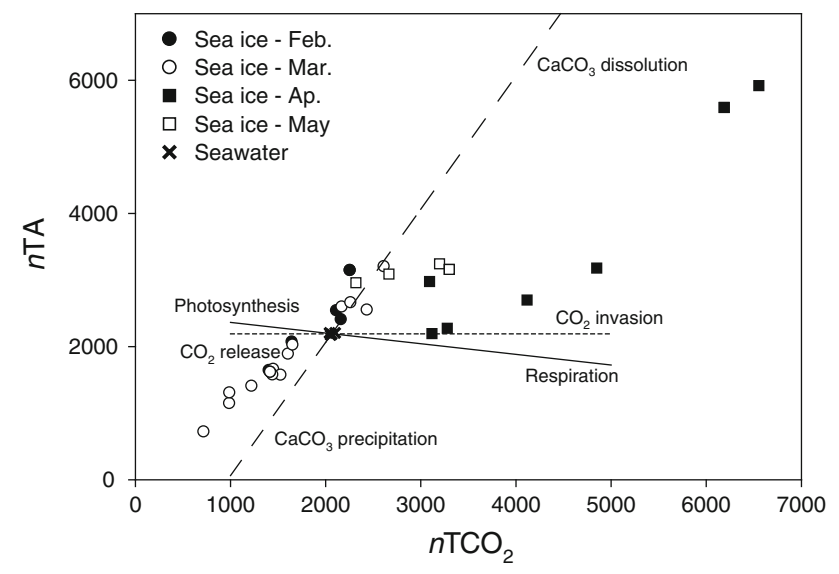

Fig. $8 n \mathrm{TA}: n \mathrm{TCO}_{2}$ (values normalized to a salinity of 33) relationship in seawater samples and bulk ice samples from February to May. The different lines represent the theoretical evolution of $\mathrm{TCO}_{2}: \mathrm{TA}$ following precipitation/dissolution of calcium carbonate (dashed line), a release or uptake of $\mathrm{CO}_{2}(\mathrm{~g})$ (dotted line) and impact of biology (solid line)

scale for values reported from the Arctic (0.2-463 $\mathrm{mg} \mathrm{C} \mathrm{m}{ }^{-2}$ day $^{-1}$; Arrigo et al. 2010 and references therein). A decrease in $\mathrm{TCO}_{2}$ was measured in the bottommost ice at the time of the algae growth, suggesting that primary production was responsible for the decrease in $\mathrm{TCO}_{2}$ (Figs. 4, 6). However, the average net biological production in the bottom of the sea ice in March was only $1.6 \mu \mathrm{mol} \mathrm{C}$ day $^{-1}$ (Fig. 6) and the average $\mathrm{TCO}_{2}$ loss in the bottom of the sea ice in March was $6.4 \mu \mathrm{mol} \mathrm{day}{ }^{-1}$, indicating that processes other than primary production influence the inorganic carbon dynamics in the sea ice.

$\mathrm{TCO}_{2}$ in sea ice is controlled by primary production and respiration by both autotrophic and heterotrophic organisms, $\mathrm{CaCO}_{3}$ precipitation/dissolution, and $\mathrm{CO}_{2}$ release/ uptake. The magnitude of the primary production and thus the potential role of the production in controlling the sea ice inorganic carbon cycle depend primarily on light availability and the size of the inorganic nutrient pool (Papadimitriou et al. 2012). The highest light attenuation coefficient of $12 \mathrm{~m}^{-1}$ was measured in March in the snow, corresponding to coefficients reported in snow cover in both the Arctic and Antarctic (Thomas 1963; Weller and Schwerdtfeger 1967; Søgaard et al. 2010). High snow reflection causes low light conditions in the sea ice. However, the highest primary production was found in the bottom of the sea ice in March (Fig. 6), where the light availability was low compared to spring, indicating that light was not the main factor controlling the primary production. However, the low primary production in the bottom of the sea ice after March suggests that the sea ice algae were nutrient-limited late in the sea ice season. Assuming that nutrient uptake by the ice algae follows the Redfield-Brzezinski ratio of 106C:16N:15Si:1P (from
Redfield et al. 1963; Brzezinski 1985), then the nitrogen $(\mathrm{N}: \mathrm{P}$ ratio $<2)$ and silicate $(\mathrm{Si}: \mathrm{P}$ ratio $<6)$ appear to have limited the sea ice algal primary production in April and May, while phosphate was found at relatively higher concentrations. This is supported by the nutrient-salinity plot for $\mathrm{NO}_{2}{ }^{-}+\mathrm{NO}_{3}{ }^{-}$in Fig. 7, which indicates depletion of $\mathrm{NO}_{2}{ }^{-}+\mathrm{NO}_{3}{ }^{-}$at the end of the sea ice season. A further factor known to influence the sea ice algal communities is grazing (Gradinger et al. 1999; Bluhm et al. 2010); however, grazing was not measured during the present study.

$\mathrm{CaCO}_{3}$ precipitation

The observed $\mathrm{CaCO}_{3}$ formation was expected (Anderson and Jones 1985; Marion 2001; Papadimitriou et al. 2004) and is consistent with the elevated $\mathrm{TA}: \mathrm{TCO}_{2}$ ratios (Fig. 4). We measured much lower $\mathrm{TCO}_{2}$ and TA concentrations within the sea ice compared to concentrations found in the underlying seawater (average TA: $\mathrm{TCO}_{2}$ ratio $=1.06$ in seawater; Fig. 4). Likewise, we found elevated TA: $\mathrm{TCO}_{2}$ ratios in the sea ice with a maximum of 1.75, as compared to the underlying seawater (Fig. 4). However, the TA: $\mathrm{TCO}_{2}$ ratios found in the sea ice in the present study are low compared to values found in other sea ice studies (Rysgaard et al. 2007, 2012; Papadimitriou et al. 2012; Geilfus et al. 2012; Rysgaard et al. 2013).

Ikaite precipitation is favored by near-freezing temperature, alkaline condition, and elevated phosphate concentrations ( $>5 \mu \mathrm{mol} \mathrm{l}^{-1}$; Bischoff et al. 1993; Buchardt et al. 2001; Selleck et al. 2007).

In this study, bulk phosphate concentrations between 0.2 and $3.1 \mu \mathrm{mol} 1^{-1}$ were measured in the sea ice, and therefore, the brine phosphate concentrations were occasionally above $5 \mu \mathrm{mol} 1^{-1}$. Furthermore, the phosphate concentrations observed in present study were 5-20 times higher than concentrations found in previous studies in the Arctic (e.g. Krembs et al. 2002; Mikkelsen et al. 2008; Søgaard et al. 2010). Sea ice temperatures during our study ranged from -6 to $0{ }^{\circ} \mathrm{C}$, which is the temperature where ikaite will form. Alkalinity condition was also satisfied as a $\mathrm{C}$-shaped $\mathrm{pH}$ profile with high $\mathrm{pH}(>9)$ in surface, and bottom sea ice layers, and slightly lower $\mathrm{pH}$ conditions (8.5) in the internal sea ice layers were calculated for February, using temperature and bulk salinity (Fig. 3), TA and $\mathrm{TCO}_{2}$ concentrations (see "Materials and methods" section; Fig. 4). A C-shaped pH profile was also observed in a recent study on experimental sea ice (Hare et al. 2013).

In the early part of the study, we measured the highest $\mathrm{CaCO}_{3}$ concentrations in the surface of the sea ice, and the concentrations decreased with depth (Fig. 5). This is similar to that described by Geilfus et al. (2013) and Rysgaard et al. (2013). 
However, just before the ice break-up, the highest $\mathrm{CaCO}_{3}$ concentration was measured in bottom of the sea ice (Fig. 5). This high $\mathrm{CaCO}_{3}$ concentration might be due to a migration of the crystals through the brine channels network or could result from the effects of surface flooding and/or gravity drainage. The average brine salinity was 67 in February, 39 in March, and 27 in April; thus, gravity drainage was only possible in February and March. A negative correlation between $\mathrm{CaCO}_{3}$ concentration and bulk salinity was evident (Table 2), which also suggests that the highest $\mathrm{CaCO}_{3}$ concentrations were found in the sea ice with low bulk salinities, i.e., in the bottom of the sea ice and/or in summer sea ice.

The concentration of $\mathrm{CaCO}_{3}$ in the sea ice was $2.13 \mathrm{~g} \mathrm{~m}^{-2}$ (Fig. 5), which compares with values from Antarctic sea ice of 0.3 to $3.0 \mathrm{~g} \mathrm{~m}^{-2}$ (Dieckmann et al. 2008) and 0.1 to $6.5 \mathrm{~g} \mathrm{~m}^{-2}$ found in the top $10 \mathrm{~cm}$ of Antarctic sea ice (Fischer et al. 2013). However, these values are one order of magnitude lower than measurements in Arctic ice by Rysgaard et al. (2012, 2013).

Assuming that sea ice is formed from surface seawater with a TA: $\mathrm{TCO}_{2}$ ratio of 1 , the TA: $\mathrm{TCO}_{2}$ ratio of 1.1-1.75 observed in the sea ice could be generated by a $\mathrm{CaCO}_{3}$ concentration of $25-120 \mu \mathrm{mol} \mathrm{CaCO} \mathrm{Cl}^{-1}$. The calculated $\mathrm{CaCO}_{3}$ concentrations are between 6 and 25 times higher than our measured $\mathrm{CaCO}_{3}$ concentrations. However, the highest calculated $\mathrm{CaCO}_{3}$ concentration compares with surface concentrations of $160-240 \mu \mathrm{mol} \mathrm{CaCO}_{3} 1^{-1}$ melted sea ice reported in the Fram Strait (Rysgaard et al. 2012). The reason for this difference is not clear but could be associated with the melting procedures used. We assume that ikaite does not dissolve if the temperature is maintained below $4{ }^{\circ} \mathrm{C}$, but ikaite could dissolve according to: $\mathrm{CaCO}_{3} \cdot 6 \mathrm{H}_{2} \mathrm{O}+$ $\mathrm{CO}_{2} \leftrightarrow \mathrm{Ca}^{2+}+2 \mathrm{HCO}_{3}^{-}+5 \mathrm{H}_{2} \mathrm{O}$ in the meltwater being in contact with atmospheric $\mathrm{CO}_{2}$ during the melting procedure. Another explanation could be that not all the changes in TA originate from $\mathrm{CaCO}_{3}$ precipitation, and so the TA concentration is higher than $\mathrm{CaCO}_{3}$ concentration.

The snow contained relatively high amounts of $\mathrm{CaCO}_{3}$, which has also been found in Antarctic snow overlying sea ice (Fischer et al. 2013). The mass of $\mathrm{CaCO}_{3}$ found in the snow ranged from 0.12 to $0.30 \mathrm{~g} \mathrm{~m}^{-2}$ (Fig. 5), which is 7 times lower than the values measured in the sea ice. An explanation for the occurrence of $\mathrm{CaCO}_{3}$ in the snow could be the upward brine expulsion, which builds up a high salinity layer on top of the ice. Subsequently, when temperature decreases, some salts may reach their solubility threshold and begin to precipitate (Geilfus et al. 2013).

The strong horizontal, vertical, and temporal variability in $\mathrm{CaCO}_{3}$ concentration suggests that $\mathrm{CaCO}_{3}$ concentration is influenced by variability in several inherent sea ice properties. We found a strong correlation between $\mathrm{CaCO}_{3}$ concentrations and bulk salinity, and inorganic nutrients
(Table 2). Pairwise correlations between all measured parameters revealed a negative relationship between $\mathrm{CaCO}_{3}$ concentration and DON in the second sampling period (Table 2), which may be due to the adverse effect of high DOM concentrations on the $\mathrm{CaCO}_{3}$ precipitation (Berner et al. 1978; Zullig and Morse 1988).

There was no clear correlation between $\mathrm{CaCO}_{3}$ and temperature (Table 2), which was unexpected as it is a key variable controlling $\mathrm{CaCO}_{3}$ release/uptake and the precipitation of $\mathrm{CaCO}_{3}$ (Papadimitriou et al. 2004). However, a similar lack of correlation was also observed in a study on Antarctic sea ice (Papadimitriou et al. 2012). This is probably because the measured temperature was not in equilibrium with the temperature conditions that led to the precipitation in the first place.

There was no effect of position for $\mathrm{CaCO}_{3}$ concentrations, DON, and bulk salinity, indicating that the parameters were homogenously distributed in the sea ice (Table 3). However, Moran's I indicates that the parameters were highly heterogeneous on the scale of meters to hundreds of meters (Table 1). Fischer et al. (2013) also found high spatial variability for $\mathrm{CaCO}_{3}$ concentration, and high spatial variability has also been observed for other sea ice biochemical and biological properties (Rysgaard et al. 2001; Granskog et al. 2005; Steffens et al. 2006; Søgaard et al. 2010). This clearly emphasizes the importance of seasonal and spatial studies and replicate sampling when collecting sea ice biogeochemical samples.

Effects of $\mathrm{CaCO}_{3}$ precipitation/dissolution and biological activity on $\mathrm{CO}_{2}$ dynamics

The changes in the TA: $\mathrm{TCO}_{2}$ ratio were to a large extent explained by $\mathrm{CaCO}_{3}$ precipitation and $\mathrm{CO}_{2}$ release/uptake from the ice (Fig. 8). This observation compares with studies by Munro et al. (2010), Fransson et al. (2011), Rysgaard et al. (2012), Papadimitriou et al. (2012), and Geilfus et al. (2012), in which most of the depletion in $\mathrm{TCO}_{2}$ was explained by processes other than biological activity. Furthermore, there was no correlation between $\mathrm{CaCO}_{3}$ and primary production or $\mathrm{BCD}$, which suggests that $\mathrm{CaCO}_{3}$ precipitation and/or dissolution is not significantly influenced by microbial activity.

The relative effects of biological activity and precipitation/dissolution of $\mathrm{CaCO}_{3}$ in influencing the air-sea $\mathrm{CO}_{2}$ exchange in sea ice can be estimated from measurements during the entire sea-ice-covered season. Using a carbon-to-Chl $a$ ratio of 20-40 for sea ice algae (Arrigo et al. 2010), an estimate of primary production of 220-540 $\mathrm{mg} \mathrm{C} \mathrm{m}^{-2}$ (data not shown) was calculated, which was low compared to the integrated $\mathrm{CaCO}_{3}$ concentration of $2,130 \mathrm{mg} \mathrm{m}^{-2}$ (Fig. 5). Furthermore, the 
integrated gross primary production of $153 \mathrm{mg} \mathrm{C} \mathrm{m}^{-2}$ recorded was also relatively low compared to the integrated $\mathrm{CaCO}_{3}$ concentration. Thus, contribution of primary production to $\mathrm{TCO}_{2}$ depletion was minor (7-25\%) compared to the contribution of $\mathrm{CaCO}_{3}$ precipitation (Fig. 8).

The primary production measured in this study might be a conservative estimate. Assuming that between 10 and $61 \%$ of the carbon fixed by photosynthesis was released as DOC (Passow et al. 1994; Chen and Wangersky 1996; Malinsky-Rushansky and Legrand 1996; Gosselin et al. 1997; Riedel et al. 2008), the average primary production in this study of $0.19 \mu \mathrm{mol} \mathrm{C} ~^{-1}$ day $^{-1}$ is equivalent to a DOC accumulation of $0.02-0.11 \mu \mathrm{mol} 1^{-1}$ day $^{-1}$. The average DOC concentration in the sea ice was $75 \mu \mathrm{mol} 1^{-1}$ (Fig. 6), which is much higher than the expected DOC accumulation calculated from the primary production. If the primary production is a conservative estimate, the contribution to the changes in $\mathrm{TCO}_{2}$ and $\mathrm{TA}$ by the net biological production might be higher.

However, a recent study with high primary production showed that only $10-20 \%$ of the changes in $\mathrm{TCO}_{2}$ could be explained by net biological production (Fransson et al. 2011). In another study by Rysgaard et al. (2012), abiotic processes including $\mathrm{CaCO}_{3}$ dissolution accounted for between 88 and $98 \%$ of the air-sea $\mathrm{CO}_{2}$ uptake, indicating that the contribution of primary production was relatively low.

Assuming that all $\mathrm{CaCO}_{3}$ dissolved within the sea ice or in the mixed layer, melting a $0.4-\mathrm{m}$-thick sea ice cover (temperature: $-1.1{ }^{\circ} \mathrm{C}$, bulk salinity: 4.4 , TA: $291 \mu \mathrm{mol} \mathrm{kg}{ }^{-1}$, and $\mathrm{TCO}_{2}: 238 \mu \mathrm{mol} \mathrm{kg}^{-1}$ ) into a 20 -m-thick mixed water layer (temperature: $0{ }^{\circ} \mathrm{C}$, salinity: 33, TA: $2,239 \mu \mathrm{mol} \mathrm{kg}{ }^{-1}$, $\mathrm{TCO}_{2}: 2,109 \mu \mathrm{mol} \mathrm{kg}^{-1}$ ) from Figs. 3 and 4 would result in a $1.5 \mathrm{ppm}$ decrease in $p \mathrm{CO}_{2}$ per week. Assuming that no $\mathrm{CaCO}_{3}$ precipitates (e.g. TA and $\mathrm{TCO}_{2}$ are both $291 \mu \mathrm{mol} \mathrm{kg}{ }^{-1}$ ), the resultant $p \mathrm{CO}_{2}$ decrease would be $0.9 \mathrm{ppm}$ per week. Using average conditions during the field campaign (Fig. 4), this corresponds to an air-sea $\mathrm{CO}_{2}$ uptake of $1.5 \mathrm{mmol} \mathrm{m}^{-2}$ sea ice day ${ }^{-1}$ (with $\mathrm{CaCO}_{3}$ ) and $1.1 \mathrm{mmol} \mathrm{m}^{-2}$ sea ice day ${ }^{-1}$ (without $\mathrm{CaCO}_{3}$ ). Therefore, dissolution of $\mathrm{CaCO}_{3}$ increased the air-sea $\mathrm{CO}_{2}$ uptake by $36 \%$ as compared with $\mathrm{CaCO}_{3}$-free sea ice. Furthermore, the abiotic sea-ice-driven $\mathrm{CO}_{2}$ is higher than the net biological production of $0.07 \mathrm{mmol} \mathrm{m}^{-2}$ day $^{-1}$ (which accounts for $4 \%$ of $\mathrm{CO}_{2}$ uptake, Fig. 6); and, therefore we conclude that the abiotic processes, including $\mathrm{CaCO}_{3}$ dissolution and $\mathrm{CO}_{2}$ uptake, played a more important role than the net biological production in the sea ice for the air-sea $\mathrm{CO}_{2}$ dynamics during this period.

Comparing the sea-ice-driven $\mathrm{CO}_{2}$ uptake with a recent study by Rysgaard et al. (2012), the uptake found in the present study is sevenfold lower. Furthermore, the amount of $\mathrm{CaCO}_{3}$ found in the present study is low compared to other studies (Dieckmann et al. 2008; Rysgaard et al. 2012; Fischer et al. 2013). Our study was performed in subarctic sea ice exposed to higher seasonal air temperatures than the aforementioned studies, which might explain the lower $\mathrm{CaCO}_{3}$ concentrations and, hence, the lower sea-ice-driven $\mathrm{CO}_{2}$ uptake.

\section{Conclusion}

Abiotic processes contributed to an air-sea $\mathrm{CO}_{2}$ uptake of $1.5 \mathrm{mmol} \mathrm{m}^{-2}$ sea ice day ${ }^{-1}$ and dissolution of $\mathrm{CaCO}_{3}$ increased the air-sea $\mathrm{CO}_{2}$ uptake by $36 \%$ as compared to a theoretical assessment of melting $\mathrm{CaCO}_{3}$-free sea ice. Furthermore, primary production only contributed marginally to $\mathrm{TCO}_{2}$ depletion of the sea ice (7-25\%), which was mainly controlled by physical export via brine drainage and $\mathrm{CaCO}_{3}$ precipitation/dissolution. The net biological production could only explain $4 \%$ of the sea-ice-driven $\mathrm{CO}_{2}$ uptake. These estimates must be considered with the caveat that for all of the parameters investigated, their distribution in the ice was highly heterogeneous. Furthermore, there was considerable temporal variability for all parameters.

Acknowledgments We thank Paul Batty, Rasmus Hedeholm, and Michael R. Schrøder for assistance in the field and in the laboratory. Furthermore, we would like to thank Asiaq (Greenland Survey) for the meteorological data provided. The study received financial support from the Greenland Climate Research Centre, and DHS was financially supported by the Commission for Scientific Research in Greenland (KVUG). David Thomas and Louiza Norman are grateful to the Royal Society and NERC for support for their participation in the work. DT and Hermanni Kaartokallio are also grateful to the Academy of Finland (FiDiPro) for the support that enabled their participation. Søren Rysgaard acknowledges the Canada Excellence Research Chair (CERC) program.

Open Access This article is distributed under the terms of the Creative Commons Attribution License which permits any use, distribution, and reproduction in any medium, provided the original author(s) and the source are credited.

\section{References}

Anderson LG, Jones EP (1985) Measurements of total alkalinity, calcium and sulphate in natural sea ice. J Geophys Res 90:9194-9198

Arrigo KR, Mock T, Lizotte MP (2010) Primary production and sea ice. In: Thomas DN, Dieckmann GS (eds) Sea ice, 2nd edn. Wiley-Blackwell Publishing, Oxford, pp 283-326

Berner R, Westrich JT, Graber R, Smitz J, Martens C (1978) Inhibition of aragonite precipitation from supersaturated seawater. Am J Sci 278:816-837

Bischoff JL, Fitzpatrick JA, Rosenbauer RJ (1993) The solubility and stabilization of ikaite $\left(\mathrm{CaCO}_{3} \cdot \mathrm{H}_{2} \mathrm{O}\right)$ from $0^{\circ}$ to $25^{\circ} \mathrm{C}$ : environmental and paleoclimatic implications for thinolite tufa. J Geol 101:21-33 
Bluhm BA, Gradinger RR, Schnack-Schiel SB (2010) Sea ice meioand macrofauna. In: Thomas DN, Dieckmann GS (eds) Sea ice, 2nd edn. Wiley-Blackwell Publishing, Oxford, pp 357-393

Brzezinski MA (1985) The Si:C:N ratio of marine diatoms: interspecific variability and the effect of some environmental variables. J Phycol 21:347-357

Buchardt B, Israelson C, Seaman P, Stockmann G (2001) Ikaite tufa towers in Ikka Fjord, southwest Greenland: their formation by mixing of seawater and alkaline spring water. J Sediment Res 71:176-189

Chen WH, Wangersky PJ (1996) Production of dissolved organic carbon in phytoplankton cultures as measured by high temperature catalytic oxidation and ultraviolet photo-oxidation methods. J Plankton Res 18:1201-1211

Clarke DB, Ackley SF (1984) Sea ice structure and biological activity in the Antarctic marginal ice zone. J Geophys Res 89:2087-2096

Cox GFN, Weeks WF (1983) Equations for determining the gas and brine volumes in sea-ice samples. J Glaciol 29:306-316

Del Giorgio PA, Cole JJ (1998) Bacterial growth efficiency in natural aquatic systems. Annu Rev Ecol Syst 29:503-541

Delille B (2006) Inorganic carbon dynamics and air-ice-sea $\mathrm{CO}_{2}$ fluxes in the open and coastal waters of the Southern Ocean. University of Liége, Liége, p 297

Delille B, Jourdain B, Borges AV, Tison JP, Delille D (2007) Biogas $\left(\mathrm{CO}_{2}, \mathrm{O}_{2}\right.$, dimethylsulfide) dynamics in spring Antarctic fast ice. Limnol Oceanogr 52:1367-1379. doi:10.4319/lo.2007.52.4.1367

Deming J (2010) Sea ice bacteria and viruses. In: Thomas DN, Dieckmann GS (eds) Sea ice, 2nd edn. Wiley-Blackwell Publishing, Oxford, pp 267-302

Dickson AG, Millero FJ (1987) A comparison of the equilibrium constants for the dissociation of carbonic acid in seawater media. Deep-Sea Res 34:1733-1743

Dickson AG, Millero FJ (1989) Corrigenda. Deep-Sea Res 36:983

Dieckmann GS, Nehrke G, Papadimitriou S, Göttlicher J, Steininger R, Kennedy H, Wolf-Gladrow D, Thomas DN (2008) Calcium carbonate as ikaite crystals in Antarctic sea ice. Geophys Res Lett. doi:10.1029/2008GL033540

Dieckmann GS, Nehrke G, Uhlig J, Göttlicher J, Gerland S, Granskog MA, Thomas DN (2010) Brief communication: ikaite $\left(\mathrm{CaCO}_{3} \times \mathrm{H}_{2} \mathrm{O}\right)$ discovered in Arctic sea ice. Crysophere Discuss 4:153-161

Eicken H, Lange MA, Dieckmann GS (1991) Spatial variability of sea-ice properties in the northwestern Weddell Sea. J Geophys Res 96:603. doi:10.1029/91JC00546

Fischer M, Thomas DN, Krell A, Nehrke G, Göttlicher J, Norman L, Meiners KM, Riaux-Gobin C, Dieckmann GS (2013) Quantification of ikaite in Antarctic sea ice. Antarct Sci 25:421-432

Fransson A, Chierici M, Yager PL, Smidt WO Jr (2011) Antarctic sea ice carbon dioxide system and controls. J Geophys Res 116:C12035. doi:10.1029/2010JC006844

Geilfus NX, Carnat G, Papakyriakou T, Tison JL, Else B, Thomas H, Shadwick E, Delille B (2012) Dynamics of $p \mathrm{CO}_{2}$ and related airice $\mathrm{CO}_{2}$ fluxes in the Arctic coastal zone (Amundsen Gulf, Beaufort Sea). J Geophys Res 117:C00G10. doi:10.1029/ 2011JC007118

Geilfus NX, Carnat G, Dieckmann GS, Halden N, Nehrke G, Papakyriakou T, Tison JL, Delille B (2013) First estimates of the contribution of $\mathrm{CaCO}_{3}$ precipitation to the release of $\mathrm{CO}_{2}$ to the atmosphere during young sea ice growth. J Geophys Res 188:244-255. doi:10.1029/2012JC007980

Gibson JAE, Trull TW (1999) Annual cycle of $\mathrm{fCO}_{2}$ under sea-ice and in open water in Prydz Bay, East Antarctica. Mar Chem 66:187-200. doi:10.1016/S0304-4203(99)00040-7

Golden KM, Ackley SF, Lytle VI (1998) The percolation phase transition in sea ice. Science 282:2238-2241. doi:10.1126/ science. 282.5397 .2238
Gosselin M, Legendre L, Therriault JC, Demers S, Rochet M (1986) Physical control of the horizontal patchiness of sea ice microalgae. Mar Ecol Prog Ser 29:289-298

Gosselin M, Levasseur M, Wheeler PA, Horner RA, Booth BC (1997) New measurements of phytoplankton and ice algal production in the Arctic Ocean. Deep Sea Res Part II 44:1623-1644

Gradinger R, Friedrich C, Spindler M (1999) Abundance, biomass and composition of the sea ice biota of the Greenland Sea pack ice. Deep Sea Res Part 2 46:1457-1472

Granskog MA, Kaartokallio H, Kuosa H, Thomas DN, Ehn J, Sonninen E (2005) Scales of horizontal patchiness in chlorophyll a, chemical and physical properties of landfast sea ice in the Gulf and Finland (Baltic Sea). Polar Biol 28:276-283

Grasshoff K, Erhardt M, Kremling K (1983) Methods of seawater analysis, 2nd revised and extended version. Verlag Chemie, Wienhiem, Deerfield Bearch, Florida, Basel

Hales B, Van Geen A, Takahashi T (2004) High-frequency measurement of seawater chemistry: flow-injection analysis of macronutrients. Limnol Oceanogr Methods 2:91-101

Hansen JW, Thamdrup B, Jørgensen BB (2000) Anoxic incubation of sediment in gas-tight plastic bags: a method for biogeochemical process studies. Mar Ecol Prog Ser 208:273-282

Haraldsson C, Anderson LG, Hasselöv M, Hult S, Olsson K (1997) Rapid, high-precision potentiometric titration of alkalinity in ocean and sediment pore water. Deep Sea Res Part I 44:2031-2044

Hare AA, Wang F, Barber D, Geilfus N-X, Galley R, Rysgaard S (2013) $\mathrm{pH}$ evolution in sea ice grown at an outdoor experimental facility. Mar Chem 154:46-64. doi:10.1016/j.marchem.2013.04. 007

Holmes RM, Aminot A, Kérouel R, Hooker BA, Peterson BJ (1999) A simple and precise method for measuring ammonium in marine and freshwater ecosystem. Can J Fish Aquat Sci 56:1801-1808

Johnson KM, Wills KD, Butler DB, Johnson WK, Wong CS (1993) Coulometric total carbon dioxide analysis for marine studies. Maximizing the performance of an automated gas extraction system and coulometric detector. Mar Chem 44:167-187. doi:10. 1016/0304-4203(93)90201-X

Juhl AR, Krembs C, Meiners K (2011) Seasonal development and differential retention of ice algae and other organic fractions from Arctic sea ice. Mar Ecol Prog Ser 436:1-16

Junge K, Eicken H, Deming JW (2004) Bacterial activity at -2 to $20^{\circ} \mathrm{C}$ in Arctic wintertime sea ice. Appl Environ Microbiol 70:550-557. doi:10.1128/AEM.70.1.550-557.2004

Kaartokallio H (2004) Food web components, and physical and chemical properties of Baltic Sea ice. Mar Ecol Prog Ser 273:49-63

Kaartokallio H, Kuosa H, Thomas DN, Granskog MA, Kivi K (2007) Changes in biomass, composition and activity of organism assemblages along a salinity gradient in sea ice subjected to river discharge. Polar Biol 30:186-197

Krembs C, Eicken H, Junge K, Deming JW (2002) High concentrations of exopolymeric substances in Arctic winter sea ice: implications for the polar ocean carbon cycle and cryoprotection of diatoms. Deep Sea Res Part 1 49:2163-2181

Krembs C, Eicken H, Deming JW (2011) Exopolymer alteration of physical properties of sea ice and implications for ice habitability and biogeochemistry in a warmer Arctic. Proc Natl Acad Sci USA 108:3653-3658

Kroon H (1993) Determination of nitrogen in water: comparison of continuous flow method with on-line UV digestion with the original Kjedahl Method. Anal Chem Acta 276:287-293

Kuparinen J, Autio R, Kaartokallio H (2011) Sea ice bacterial growth rate, growth efficiency and preference for inorganic nitrogen sources in the Baltic Sea. Polar Biol 34:1361-1373 
Lazar B, Loya Y (1991) Bioerosion of coral reefs-a chemical approach. Limnol Oceanogr 36:377-383. doi:10.4319/lo.1991. 36.2.0377

Lee H-F, Yang TF, Lan TF (2005) Fumarolic gas composition of the Tatun Volcano Group, Northern Taiwan. TAO 16:843-864

Legendre P, Legendre L (1998) Developments in environmental ecology, 20. Numerical ecology, 2nd English ed. Elsevier Science BV, Amsterdam

Leppäranta M, Manninen T (1988) The brine and gas content of sea ice with attention to low salinities and high temperatures. Finnish Inst. Marine Res. Internal report, p 14

Lewis E, Wallace D (2012): The program CO2SYS.EXE can be downloaded at: http://cdiac.esd.ornl.gov/oceans/co2rprtnbk. html, 2012

Lin YP, Singer PC (2006) Inhibition of calcite precipitation by orthophosphate: speciation and thermodynamic considerations. Geochimica Cosmochim Acta 70:2530-2539

Long MH, Koopmans D, Berg P, Rysgaard S, Glud RN, Søgaard DH (2011) Oxygen exchange and ice melt measured at the ice-water interface by eddy correlation. Biogeosci Discuss 8: 11255-11284. doi:10.5194/bgd-8-11255-2011

Loose B, Miller LA, Elliott S, Papakyriakou T (2011) Sea ice biogeochemistry and material transport across the frozen interface. Ocean 24:203-218

Malinsky-Rushansky NZ, Legrand C (1996) Excretion of dissolved organic carbon by phytoplankton of different sizes and subsequent bacterial uptake. Mar Ecol Prog Ser 132:249-255

Marion GM (2001) Carbonate mineral solubility at low temperatures in the $\mathrm{Na}-\mathrm{K}-\mathrm{Mg}-\mathrm{Ca}-\mathrm{H}-\mathrm{Cl}-\mathrm{SO}_{4}-\mathrm{OH}-\mathrm{HCO}_{3}-\mathrm{CO}_{3}-\mathrm{CO}_{2}-\mathrm{H}_{2} \mathrm{O}$ system. Geochim Cosmochim Acta 65:1883-1896

Mehrbach C, Culberson H, Hawley JE, Pytkowicz RM (1973) Measurement of the apparent dissociation constants of carbonic acid in seawater at atmospheric pressure. Limnol Oceanogr 18:897-907

Meiners K, Krembs C, Gradinger R (2008) Exopolymer particles: microbital hotspots of enchanced bacterial activity in Arctic fast ice (Chukchi Sea). Aquat Microb Ecol 52:195-207

Middelboe M, Glud RN, Sejr MK (2012) Bacterial carbon cycling in a subarctic fjord: a seasonal study on microbial activity, growth efficiency, and virus-induced mortality in Kobbefjord, Greenland. Limnol Oceanogr 57:1732-1742

Mikkelsen DM, Rysgaard S, Glud RN (2008) Microalgal composition and primary production in Arctic sea ice: a seasonal study from Kobbefjord (Kangerluarsunnguaq), West Greenland. Mar Ecol Prog Ser 368:65-74

Miller L, Papkyriakou TEC, Deming J, Ehn J, Macdonald R, Mucci A, Owens O, Raudsepp M, Sutherland N (2011) Carbon dynamics in sea ice: a winter flux time series. J Geophys Res 116. doi: $10.1029 / 2009 J C 006058$

Moran PAP (1950) Notes on continuous stochastic phenomena. Biometrika 37:17-23

Mortensen J, Lennert K, Bendtsen J, Rysgaard S (2011) Heat sources for glacial melt in a sub-Arctic fjord (Godthåbsfjord) in contact with the Greenland Ice Sheet. J Geophys Res 116:c01013. doi:10.1029/2010JC006528

Munro DR, Dunbar RB, Mucciarone DA, Arrigo KR, Long MC (2010) Stable isotope composition of dissolved inorganic carbon and particulate organic carbon in sea ice from the Ross Sea, Antarctica. J Geophys Res Ocean 115:C09005. doi:10.1029/ 2009JC005661

Nedashkovsky AP, Khvedynich SV, Petovsky TV (2009) Alkalinity of sea ice in the high-latitudinal arctic according to the surveys performed at north pole drifting station 34 and characterization of the role of the arctic in the $\mathrm{CO}_{2}$ exchange. Mar Chem 49:55-63. doi:10.1134/s000143700901007x
Nomura D, Eicken H, Gradinger R, Shirasawa K (2010) Rapid physically driven inversion of the air-sea ice $\mathrm{CO}_{2}$ flux in the seasonal landfast ice off Barrow, Alaska after onset surface melt. Cont Shelf Res 30:1998-2004

Notz D, Worster MG (2009) Desalination processes of sea ice revisited. J Geophys Res 114:1-10. doi:10.102972008JC004885

Papadimitriou S, Kennedy H, Kattner G, Dieckmann GS, Thomas DN (2004) Experimental evidence for carbonate precipitation and $\mathrm{CO}_{2}$ degassing during sea ice formation. Geochim Cosmochim Acta 68:1749-1761

Papadimitriou S, Thomas DN, Kennedy H, Haas C, Kuosa H, Krell A, Dieckmann GS (2007) Biogeochemical composition of natural sea ice brines from the Weddell Sea during early austral summer. Limnol Oceanogr 52:1809-1823

Papadimitriou S, Kennedy H, Norman L, Kennedy DP, Dieckmann GS, Thomas DN (2012) The effect of biological activity, $\mathrm{CaCO}_{3}$ mineral dynamics and $\mathrm{CO}_{2}$ degassing in the inorganic carbon cycle in sea ice in late winter-early spring in the Weddell Sea, Antarctica. J Geophys Res 117:C08011. doi:10.1029/2012 JC008058

Papakyriakou T, Miller L (2011) Springtime $\mathrm{CO}_{2}$ exchange over seasonal sea ice in the Canadian Arctic Archipelago. Ann Glaciol 52:1-10

Passow U, Alldredge AL, Logan BE (1994) The role of particulate carbohydrate exudates in the flocculation of diatoms blooms. Deep Sea Res I 41:335-357

Petrich C, Eicken H (2010) Growth, structure and properties of sea ice. In: Thomas DN, Dieckmann GS (eds) Sea ice, 2nd edn. Wiley-Blackwell Publishing, Oxford, pp 425-469

Platt T, Gallegos CL, Harrison WG (1980) Photoinhibition of photosynthesis in natural assemblages of marine phytoplankton. J Mar Res 38:687-701

Pomeroy LR, William JW (2001) Temperature and substrate as interactive limiting factors for marine heterotrophic bacteria. Aquat Microbiol Ecol 23:187-204

Qian J, Mopper K (1996) Automated high-performance, hightemperature combustion total organic carbon analyzer. Anal Chem 68:3090-3097. doi:10.1021/AC960370Z

Redfield AC, Ketchum BH, Richards FA (1963) The influence of organisms on the composition of seawater. In: Hill MN (ed) The composition of sea-water and comparative and descriptive oceanography. Wiley-Intersciences, New York, pp 26-87

Riedel A, Michel C, Gosselin M, LeBlanc B (2008) Winter-spring dynamics in sea-ice carbon cycling in the coastal Arctic Ocean. J Mar Syst 74:918-932

Rivkin RB, Legendre L (2001) Biogenic carbon cycling in the upper ocean: effects of microbial respiration. Science 291:2398-2400

Rysgaard S, Glud RN (2004) Anaerobic $\mathrm{N}_{2}$ production in Arctic sea ice. Limnol Oceanogr 49:86-94

Rysgaard S, Kuhl M, Glud RN, Hansen JW (2001) Biomass, production and horizontal patchiness of sea ice algae in a high-Arctic fjord (Young Sound, NE Greenland). Mar Ecol Prog Ser 223:15-26

Rysgaard S, Glud RN, Sejr MK, Bendtsen J, Christensen PB (2007) Inorganic carbon transport during sea-ice growth and decay: a carbon pump in polar seas. J Geophys Res 112:111-118

Rysgaard S, Bendtsen J, Delille B, Dieckmann GS, Glud RN, Kennedy H, Mortensen J, Papadimitriou S, Thomas DN, Tison JL (2011) Sea ice contribution to the air-sea $\mathrm{CO}_{2}$ exchange in the Arctic and Southern Oceans. Tellus Ser B 63:823-830. doi:10. 1111/J.1600-0889-2011.005471.x

Rysgaard S, Glud RN, Lennert K, Cooper M, Halden N, Leaky R, Hawthorne FC, Barber D (2012) Ikaite crystals in melting sea ice-implications for $p \mathrm{CO}_{2}$ and $\mathrm{pH}$ levels in Arctic surface waters. Cryosphere 6:1015-1035. doi:10.51947tcd-6-015-2012 
Rysgaard S, Søgaard DH, Cooper M, Pućko M, Lennert K, Papakyriakou TN, Wang F, Geilfus NX, Glud RN, Ehn J, McGinnis DF, Attard K, Sievers J, Deming JW, Barber D (2013) Ikaite crystal distribution in winter sea ice and implications for $\mathrm{CO}_{2}$ system dynamics. Cryosphere 7:707-718. doi:10.5194/tc-7707-2013

Selleck BW, Carr PF, Jones BG (2007) A review and synthesis of Glendonites (Pseudomorphs after ikaite) with new data. Assessing applicability as recorders of ancient coldwater conditions. J Sediment Res 77:980-991

Semiletov I, Makshtas A, Syun-Ichi A (2004) Atmospheric $\mathrm{CO}_{2}$ balance: the role of Arctic sea ice. Geophys Res Lett 31:L05121. doi:10.1029/2003GL017996

Semiletov IP, Pipko I, Repina I, Shakhova NE (2007) Carbonate chemistry dynamics and carbon dioxide fluxes across the atmosphere-ice water interfaces in the Arctic Ocean: Pacific sector of the Arctic. J Mar Syst 66:204-226. doi:10.1016/j. jmarsys.2006.05.012

Smith REH, Clement P (1990) Heterotrophic activity and bacterial productivity in assemblages of microbes from Sea ice in the high Arctic. Polar Biol 10:351-357

Søgaard DH, Kristensen M, Rysgaard S, Glud RN, Hansen PJ, Hilligsøe KM (2010) Autotrophic and heterotrophic activity in Arctic first-year sea ice: seasonal study from Malene Bight, SW Greenland. Mar Ecol Prog Ser 419:31-45

Steffens M, Granskog MA, Kaartokallio H, Kuosa H, Luodekari K, Papadimitriou S, Thomas DN (2006) Spatial variation of biogeochemical properties of landfast sea ice in the Gulf of Bothnia, Baltic Sea. Ann Glaciol 44:80-87
Thomas CW (1963) On the transfer of visible radiation through sea ice and snow. J Glaciol 4:481-484

Thomas DN, Papadimitriou S, Michel C (2010) Biogeochemistry of sea ice. In: Thomas DN, Dieckmann GS (eds) Sea ice, 2nd edn. Wiley-Blackwell Publishing, Oxford, pp 425-469

Tison J-L, Haas C, Gowing MM, Sleewaegen S (2002) Tank study of physico-chemical controls on gas content and composition during growth of young sea ice. J Glaciol. doi:10.3189/ 172756502781831377

Underwood GJC, Fietz S, Papadimitriou S, Thomas DN, Dieckmann GS (2010) Distribution and composition of dissolved extracellular polymeric substances (EPS) in Antarctic sea ice. Mar Ecol Prog Ser 404:1-19

Weeks WF, Ackley SF (1986) The growth, structure and properties of sea ice, Chapter 1 of The Geophysics of Sea Ice, NATO ASI Series, Series B, Physics Vol. ed. N. Untersteiner, Plenum Press, NY

Weller G, Schwerdtfeger P (1967) Radiation penetration in Antarctic plateau and sea ice. Polar Meteorol World Meteorol Org Tech Note 87:120-141

Zeebe RE, Wolf-Gladrow D (2001) $\mathrm{CO}_{2}$ in seawater: equilibrium, kinetics, isotopes. Elsevier, Amsterdam

Zemmelink HJ, Delille B, Tison JL, Hintsa EJ, Houghton L, Dacey JW (2006) $\mathrm{CO}_{2}$ deposition over the multi-year ice of the western Weddell Sea. Geophys Res Lett 33:L13606. doi:10.1029/ 2006GL026320

Zullig JJ, Morse JW (1988) Interaction of organic acids with carbonate mineral surfaces in seawater and related solutions: I. Fatty acid adsorption. Geochim Cosmochim Acta 52:1667-1678 